\title{
COERCING COMPLIANCE WITH THE ICC: EMPIRICAL ASSESSMENT AND THEORETICAL IMPLICATIONS
}

\author{
Marco Bocchese*
}

This article investigates the circumstances under which the threat of ICC prosecution has proved successful in deterring the commission or escalation of mass atrocities. Through a within-case analysis of the domestic situation of Côte d'Ivoire between 2004 and 2011, I find evidence that successful deterrence is a function of two main causal variables, namely the likelihood of arrest or punishment and the leaders' outlook on retaining power in the short-run. I argue that specific values on these variables combined to determine how the threat of ICC prosecution successfully deescalated violence in Côte d'Ivoire in the fall of 2004. This article challenges a set of assumptions widely employed by legal scholars in theorizing international deterrence, stresses the importance of bringing back the relational character of deterrence and concludes by advocating greater attention to the political conditions surrounding ICC operations.

INTRODUCTION

I. MiXING APPLES AND ORANGES? THE ICC AND THE CHALlENGE OF APPLYING DOMESTIC DETERRENCE THEORIES TO INTERNATIONAL LAW.

A. The ICC and its Deterrent Impact: Game Changer or House of Cards?

II. ARMING THE THREAT OF CRIMINAL SANCTIONS: LESSONS ON DETERRENCE FROM INTERNATIONAL RELATIONS (IR) THEORY... 385

A. New Concepts for Old Theories: Immediate and Extended Deterrence

B. Beyond Rational Deterrence Theory: Signaling the Threat of Sanctions to Potential Atrocities Perpetrators 390

C. From Practice to Theory: An Inductive Approach for Theorizing International Deterrence 400

D. Outside the Political Vacuum: The Need for Understanding African Politics

III. INTERNATIONAL DETERRENCE AT WORK: THE CASE OF CÔTE D'IVOIRE 416 


\section{INTRODUCTION}

Well before the International Criminal Court (ICC) entered into force on July 1, 2002, a lively debate had flourished over its deterrent potential. ${ }^{1}$ Scholars and professionals alike began to ask crucial questions about the Court, including perhaps the most important (and contentious) of all: Can the ICC really deter potential perpetrators from committing "atrocity crimes"? ${ }^{2}$ If so, how is the ICC different from other international criminal tribunals (ICTs), which have so far failed to bring about system-wide deterrence? Almost fourteen years into ICC operations, the above-mentioned debate is far from settled. Not only is there still no agreement as to whether the ICC contributes to the deterrence of atrocities, but there is also a growing body of literature that claims, under particular circumstances, it actually exacerbates, rather than restrains, the use of violence. ${ }^{3}$ That said, the notion of deterrence is

* Marco Bocchese, Ph.D. candidate, Northwestern University (2017 expected); LL.M. Northwestern University (2010); J.D. University of Verona, Italy (2007). For helpful comments, I would like to thank Karen Alter, Jacqueline McAllister, and William Reno. Earlier versions of this article were presented at the annual convention of the International Studies Association, in New Orleans, Louisiana, February 18-21, 2015; and the annual conference of the Midwest Political Science Association, Chicago, Illinois, April 16-19, 2015. Financial assistance from the Northwestern University's Program of African Studies and the Buffett Institute for Global Studies is gratefully acknowledged. For excellent editorial assistance, I thank Alexandra Wilson, Kyla Barranco, and Simone Fabiilli.

1. On the vast scholarly commentary on the ICC preventive impact, see, inter alios, David Wippman, Atrocities, Deterrence, and the Limits of International Justice, 23 Fordham InT'L L.J. 473, 473-44 (1999); Tom Ginsburg, Clash of Commitments at the International Criminal Court, 9 CHI. J. INT'L L. 499, 501-02 (2009).

2. David J. Scheffer, Atrocity Crimes Litigation During 2009, 8 Nw. J. INT'L HuM. RTS. 1, 236 (2010) (categorizing atrocity crimes as the "crime of genocide, crimes against humanity, and war crimes").

3. See Michael P. Scharf, The Amnesty Exception to the Jurisdiction of the International Criminal Court, 32 CORNELL INT'L L.J. 507, 507-08 (1999) [hereinafter The Amnesty Exception]; Michael L. Smidt, The International Criminal Court: An Effective Means of Deterrence, 167 MiL. L. REV. 156, 180 (2001); Jack Goldsmith \& Stephen D. Krasner, The Limits of Idealism, 132 Daedalus 47, 48 (2003); Julian Ku \& Jide Nzelibe, Do International Criminal Tribunals Deter or Exacerbate Humanitarian Atrocities?, 84 Wash. U. L. ReV. 777, 777-78 (2006); Adam Branch, Uganda's Civil War and the Politics of ICC Intervention, 21 ETHICS \& INT'L AfF. 179, 189 (2007). 
literally ubiquitous in the scholarship on the ICC; and it can hardly be otherwise since one of its stated goals is in fact "to contribute to the prevention of [grave] crimes" that "threaten the peace, security and wellbeing of the world." Scholars surveying statements issued by public figures have shown that from the onset, deterrence has belonged in the official rhetoric on what the Court is expected to accomplish. ${ }^{5}$ One oftcited example of such statements is by then-United Nations (UN) Secretary-General Kofi Annan, who greeted the Rome Statute's entry into force wishing the newly born court would serve the purpose of deterring future war criminals and eradicating impunity for all those who abuse human rights. $^{6}$ Former ICC President San-Hyun Song lists deterrence as one of the four effects substantiating the Court's preventive potential ${ }^{7}$ and further identifies it as "the most direct preventative effect of international justice." 8

4. Rome Statute of the International Criminal Court, art. 16, U.N. Doc. A/CONF.183/9 (July 17, 1998) [hereinafter Rome Statute].

5. See, e.g., Christopher W. Mullins \& Dawn L. Rothe, The Ability of the International Criminal Court to Deter Violations of International Criminal Law: A Theoretical Assessment, 10 INT'L CRIM. L. REV. 771, 772 (2010); Dawn L. Rothe \& Isabel Schoultz, Law, Courts, and Punishment as Deterrent Mechanisms?, in CRIMINAL Justice In InTERnATIONAL Society 151-54 (Willem de Lint et al. eds., Routledge 2014); David Bosco, The International Criminal Court and Crime Prevention: Byproduct or Conscious Goal, 19 Mich. ST. INT'L L. REV. 163, 164, 170, 172 (2010).

6. James F. Alexander, The International Criminal Court and the Prevention of Atrocities: Predicting the Court's Impact, 54 VILL. L. REV. 1, 10 (2009).

7. Sang-Hyun Song, Preventive Potential of the International Criminal Court, 3 ASIAN J. INT'L L. 203, 206 (2013).

8. Id. at 207. On this point, it bears recalling that the ICC is not the first ICT to invoke deterrence. James Meernik reminds us that both the charters of the International Criminal Tribunal for the former Yugoslavia (ICTY) and the International Criminal Tribunal for Rwanda (ICTR) "make reference to the deterrent function of international justice." James Meernik, Justice, Power and Peace: Conflicting Interests and the Apprehension of ICC Suspects, 13 INT'L CRIM. L. REV. 169, 175 (2013). Further, the ICTR Trial Chamber employed deterrence as a guiding principle in determining the severity of sentences in hopes of dissuading future perpetrators. Alexander, supra note 6, at 10 n.37. Yet, from such remarks it remains difficult to speculate on whether or not claims on the ICC deterrent impact are more than simply cheap talk. Similarly, see Mullins \& Rothe, supra note 5, at 772. 
Politically, international criminal justice embodies an ambitious normative project that remained dormant for half a century after the trials staged in Nuremberg and Tokyo and then timidly re-emerged after the Cold War ended. ${ }^{9}$ It was only after state-sponsored episodes of mass violence in former Yugoslavia and Rwanda, which shocked the conscience of key global actors (in primis the United States), that the idea of an international criminal justice system gained enough momentum and took off. ${ }^{10}$ However, the two ad hoc tribunals were conceived by the international community as a response to alreadycommitted atrocities rather than an instrument to prevent future ones. ${ }^{11}$ The above timeline in fact suggests that deterrence played at best a marginal part in informing decision-makers' decisions at the onset of the international criminal justice enterprise. Recent work in international law and politics has so far failed to solve the conundrum of how ICTs can improve compliance with international criminal law (ICL) through deterrent mechanisms. ${ }^{12}$ As a result, the current state of the field is surprisingly discouraging; despite efforts to point out and reckon with the issue above, scholars nevertheless have failed to provide compelling solutions thereto. ${ }^{13}$ James Alexander, for instance, notices that the most

9. On the importance of the geopolitical climate for establishing and further enhancing the ICL regime, see John Hagan, Justice in the Balkans: Prosecuting War Crimes in the Hague Tribunal 28-30 (2003).

10. On this point, see M. Cherif Bassiouni, From Versailles to Rwanda in Seventy-five Years: The Need to Establish a Permanent International Criminal Court, 10 HARV. Hum. RTS. J. 11, 59-61 (1997); Song, supra note 7, at 204; DAVID BosCO, RougH Justice: The International Criminal Court in a World of Power Politics 38 (2014).

11. Alexander, supra note 6, at 36 (citing GARY Jonathan Bass, StAy THE Hand of Vengeance: The Politics of War CRimes Tribunals 207 (2000)).

12. For a critical assessment of the state of the field, see Ginsburg, supra note 1; Alexander, supra note 6; Kate Cronin-Furman, Managing Expectations: International Criminal Trials and the Prospects for Deterrence of Mass Atrocity, 7 InT'L J. Transitional Just. 434, 435 (2013). On the ICTY, see Payam Akhavan, Justice in the Hague, Peace in the Former Yugoslavia?, 20 Hum. RTs. Q. 737, 744 (1999).

13. Alexander, supra note 6 , at 55; see also Cronin-Furman, supra note 12; Payam Akhavan, Are International Criminal Tribunals a Disincentive to Peace?: Reconciling Judicial Romanticism with Political Realism, 31 Hum. RTs. Q. 624, 636 (2009). 
serious - and enduring, I shall add - problem affecting the scholarship either affirming or denying ICTs' preventive potential is "the tendency on both sides of the debate to state relatively strong conclusions without much evidentiary support." 14 Dawn Rothe and Isabel Schoultz warn us against taking deterrence as a certainty, ${ }^{15}$ while Christopher Mullins and Dawn Rothe maintain that "[ICC] [p]ractitioners and scholars routinely assume a probability at best, to an assumption of sureness, of a powerful deterrent effect." $" 16$

Bearing this shortcoming in mind, this Article investigates the circumstances under which the threat of ICC prosecution has proved successful in deterring the commission or escalation of mass atrocities. Thus, this Article is conceived to be an empirically driven project with an ultimate end of providing new hints for (better) theoretical deterrence at the international level. Within the broader literature on the ICL regime and its alleged deterrent effects, this Article also represents a call for caution. Writing in 2001, Christopher Rudolph sought to determine how an effective atrocities regime could eventually be used "to manage violent conflict and reduce the likelihood of future transgressions." ${ }^{17}$ This Article draws extensively on Rudolph's work and builds on many of his findings, including the need to keep in mind realist factors (e.g., the strategic interests of the most powerful states), to consider greater institutional flexibility in order to increase regime strength, and to move beyond purely legalistic views of war crimes adjudication so as to capture the political dimensions involved in regime formation. ${ }^{18}$ Yet, I hereby contend that, as of 2015 , the scholarship dedicated to the study of legal deterrence at the international level has surprisingly limited knowledge of cases wherein the threat of ICC prosecution has proven successful in deterring potential perpetrators. Further, scholars have not

14. Alexander, supra note 6, at 55 .

15. Rothe \& Schoultz, supra note 5, at 151 .

16. Mullins \& Rothe, supra note 5, at 772.

17. Christopher Rudolph, Constructing an Atrocities Regime: The Politics of War Crimes Tribunals, 55 InT'L ORG. 655, 656 (2001).

18. Id. at 686-87. Jeffrey W. Legro also makes reference to a "'strategic realist' view" of international law, although his argument applies to compliance with the law rather than regime formation. Jeffrey W. Legro, Which Norms Matter? Revisiting the "Failure" of Internationalism, 51 INT'L ORG. 31, 45 (1997). 
yet identified those causal factors determining the above threat to work differently across cases - a task the Rome Statute has made easier at the methodological level, for it allows for consistency of the law over time and space. This is not to deny that Rudolph pointed his peers in the right direction. Rather, I posit that only upon gaining a better understanding of the causal mechanisms underpinning new theories of legal deterrence at the international level will it be possible to engage the question of how political actors can strategically employ the threat of ICC prosecution as a conflict resolution resource or political bargaining chip.

The first logical step of this Article is therefore to identify a mostlikely case, that is, a case where the threat of ICC prosecution is said to have dissuaded potential perpetrators from acting in violation of ICL norms. To this end, in the empirical section I carry out a thorough within-case analysis of Côte d'Ivoire (CIV) from September 2002when the first Ivorian civil war broke out - until April 2011 - when the second Ivorian civil war ended with President Laurent Gbagbo's arrest. ${ }^{19}$ Numerous analytical and methodological reasons suggest that Côte d'Ivoire is an ideal case study for the task I purport to address in this Article. First, I choose to look at the example of Côte d'Ivoire because scholars agree that, with the looming specter of ICC prosecution, senior state leaders decided to deescalate violence driven by the fear of the consequences they could otherwise face. ${ }^{20}$ At first glance, the sequence of events supports scholarly contentions that deterrence was at work in

19. Not all scholars consider these two conflicts as separate events, and, instead, believe that the conflicts were two rounds of violence driven by the same grievance. See, e.g., Laia Balcells, Rivalry and Revenge: The Politics of Violence in Civil War (forthcoming 2016) (on file with author).

20. Akhavan, supra note 13, at 625, 640; Bosco, supra note 5, at 177; Michael McGovern, conversely, states that "the [mere] threat of being disqualified or rendered illegitimate, whether this meant imprisonment or simply (local or international) censure does appear to have played a role in Côte d'Ivoire in making some of the combatants 'think twice' about committing atrocities or allowing atrocities to be committed under their command." Michael McGovern, Proleptic Justice: The Threat of Investigation as a Deterrent to Human Rights Abuses in Côte d'Ivoire, in Mirrors of Justice: LAW AND Power IN THE Post-Cold War ERA 67, 81 (Kamari Maxine Clarke \& Mark Goodale eds., 2014). 
this case. ${ }^{21}$ A causal mechanism, deterrence, seemingly links together an observed outcome - restraint in the use of violence - to its alleged cause - the mere existence of the ICL regime along with an operating institution tasked with enforcing ICL norms. Moreover, the proposed independent variable is both logically and temporally prior to the observed outcome. By selecting Côte d'Ivoire as a case study, I prove that the mere existence of the ICL regime, thenceforth "administered" by the ICC, is but a trivial condition-that is formally necessary, yet endowed with limited explanatory power. ${ }^{22}$

The second (methodological) reason for choosing Côte d'Ivoire is that it presents variation in outcomes over time. This entails that, even controlling for a wide array of legal and non-legal variables, deterrence did not always succeed in shaping Ivorian leaders' decisions. It further follows that, since the legal scaffolding has been held constant over time, the cause of why deterrence has at times proven successful must be exogenous to the ICL regime and the ICC as the governing institution thereof.

Third, this qualitative study provides a starting point for future comparative work on cases falling under ICC scrutiny. While the study of a single case is insufficient to extract the generally-valid assertions necessary for theory-building, this Article seeks to pinpoint untestedbut testable - hypotheses to be later developed into mid-level theories on how ICTs can be used "in establishing justice and promoting peace." 23

Substantially, this Article stresses the limits of modern legal deterrence theory (LDT). Within the debate on the relationship between peace and justice, I contend that envisaging amnesties could, under

21. Mainstream methodologists maintain that "[s]ingle-case studies are particularly useful in challenging already-existing theories, if these theories are precisely formulated." Henry E. Brady et al., Refocusing the Discussion on Methodology, in Rethinking Social Inquiry: Diverse ToOls, Shared Standards 28 (Henry E. Brady \& David Collier eds., 2d ed. 2010).

22. A comment on this point is due. The intention here is not to downplay the Court's importance, but rather to identify causal factors at play in both within-case and cross-case analysis. Since a number of countries, including state parties to the ICC, have experienced mass atrocities after the ICC has been established, the Court's existence cannot be regarded as a causal variable retaining great explanatory power.

23. Rudolph, supra note 17, at 687. 
certain circumstances, enhance rational deterrence theory (RDT). Indeed, the latter pivots on a rigid incentive structure that is not designed to cover instances where exogenous ${ }^{24}$ threats alter payoffs by discounting the cost of non-compliance with the laws; in similar situations, noncompliance becomes a "second-worst" outcome. ${ }^{25}$ When making decisions under threats to their physical or political survival, state and rebel leaders alike are expected to privilege short-term gains over longterm considerations. ${ }^{26}$ Introducing amnesties may provide the necessary positive payoff for actors who have fallen out of the RDT frame and can thus exacerbate violence at no additional cost. ${ }^{27}$ But rethinking RDT is neither the only nor the most important focus of this Article. Indeed, the key goal of this Article is to challenge a set of assumptions undergirding domestic theories of legal deterrence-assumptions that are now, almost uncritically, applied to the international realm. ${ }^{28}$

24. The term "exogenous" is hereby used as a synonym for "non-state." In a Weberian model, the state has the monopoly of legitimate violence, which means it is the only entity with the authority to threaten criminal punishment for breaking the law. However, this is an ideal type, and, as such, it does not take into account non-state actors who pose a credible threat to decision-makers. Considering exogenous threats becomes even more important in situations of civil conflict, where the authority of the state is necessarily contested and often compromised. Max Weber, Politics as a Vocation, in From Max Weber: EsSAys in Sociology 78 (H.H. Gerth \& C. Wright Mills eds., 1991).

25. See Cronin-Furman, supra note 12, at 444-45; Ku \& Nzelibe, supra note 3, at 793.

26. Brian Job, in writing about Third World states facing a security environment that he labels an "insecurity dilemma," maintains that "[s]tates (more appropriately, regimes) are preoccupied with the short-term; their security and their physical survival are dependent on the strategies they pursue for the moment." Brian L. Job, The Insecurity Dilemma: National Regime, and State Securities in the Third World, in THE INSECURITY Dilemma: National Security of Third World States 27 (Brian L. Job ed., 1992).

27. See Matthew Brubacher, The ICC Investigation of the Lord's Resistance Army: An Insider's View, in The Lord's Resistance ARMY: Myth and Reality 264-66 (Tim Allen \& Koen Vlassenroot eds., 2010); Linda M. Keller, Achieving Peace with Justice: The International Criminal Court and Ugandan Alternative Justice Mechanisms, 23 ConN. J. INT'L L. 209, 211 (2007); Bosco, supra note 5, at 182-83. On the short-term incompatibility of achieving peace and obtaining justice, see also Michael P. Scharf, From the Exile Files: An Essay on Trading Justice for Peace, 63 WASH. \& LEE L. REv. 339, 342 (2006).

28. See Smidt, supra note 3, at 182-84; Mullins \& Rothe, supra note 5, at 772; Rothe \& Schoultz, supra note 5, at 155. 
Particularly problematic at the international level are two assumptions that practitioners and scholars hardly consider when pondering the preventive impact of ICTs (including the ICC). ${ }^{29}$ The first assumption, to be quickly revisited and dismissed, is the tendency to conflate the threatener (he who voices the threat of punishment) with the enforcer (he who is tasked with apprehending suspects and inflicting sanctions). This tendency is justified at the domestic level, where the state latu sensu plays both roles; conversely, ICTs lack empowered policing agencies and therefore must rely on state cooperation. ${ }^{30}$ The second assumption is specular to the first. Scholars agree that not all individuals are equally responsive to the threat of sanctions; those who have more at stake are more likely to desist from committing or otherwise facilitating criminal activity. ${ }^{31}$ To this end, the ICC's lasting focus on Africa (as of May 2015, the Office of the Prosecutor is investigating nine situations in eight African countries and conducting two preliminary examinations on Guinea and Nigeria) may actually help furthering our understanding of how deterrence works in practice by providing geopolitical context to the conceptualization of international deterrence. ${ }^{32}$

This Article takes shape in three parts. First, it reviews legal deterrence theories and outlines the novelties introduced by ICC norms and practices. Recent improvements notwithstanding, in this Article I

29. "Mark Drumbl has ... [warned] that international lawyers too often import domestic criminological assumptions into the international realm whole cloth." Alexander, supra note 6, at 15 n.60 (citing Mark A. Drumbl, Collective Violence and Individual Punishment: The Criminality of Mass Atrocity, 99 Nw. U.L. REV. 539, 545-46 (2004)). This Article argues that researchers have largely ignored Drumbl's warning.

30. See Bosco, supra note 5, at 169.

31. In the field of criminology, researchers have long studied the relationship between "social location and position" and deterrence. Mullins \& Rothe, supra note 5, at 774; see, e.g., Rothe \& Schoultz, supra note 5, at 156; Raymond Paternoster \& Sally Simpson, Sanction Threats and Appeals to Morality: Testing a Rational Choice Model of Corporate Crime, 30 L. \& SoC'Y REV. 549, 550-51 (1996). A similar point in the field of international law and politics has been made by Hun Joon Kim \& Kathryn Sikkink, Explaining the Deterrence Effect of Human Rights Prosecutions for Transitional Countries, 54 INT'L STUD. Q. 939, 940-41 (2010).

32. On this point, David Bosco notices that " $[\mathrm{t}]$ ension has emerged between the court and many African member states over the emphasis on African conflicts." Bosco, supra note 5, at 198. 
argue that legal scholars can learn tremendously by importing key concepts from political science. I conclude the first section by advocating for greater flexibility in the application of existing ICC norms. Second, I introduce the concepts of extended and immediate deterrence and adapt them to the scholarship on legal deterrence. Once identities and preferences are attached to the players involved in the "threat game," it becomes clear that theories other than RDT are better equipped to explain variation both across and within cases. The main takeaway from this section lies in the acknowledgement that it is no longer possible to disregard the identity of those who face the threat of ICC prosecution and those who are willing to bear the political and non-political costs of enforcing ICC decisions. ${ }^{33}$ Successful deterrence is a function of the specific relationship running between these two players. Third, I present the Côte d'Ivoire case study. This section emphasizes variations in outcomes while holding players constant, which I explain through one of my two independent variables: leadership survival. The latter, in turn, moves the focus beyond mere considerations of power; it does so by drawing on the scholarship on perceptions, spearheaded by Robert Jervis, and the above-said scholarship on social position. ${ }^{34}$ The overall goal is to further our understanding of the ICC preventive potential by placing court operations "in a world of power politics," 35 rather than in a legal vacuum. Finally, the case study of Côte d'Ivoire lends support to the claim that the non-legal circumstances surrounding the threat of international prosecution determine, case by case, whether the ICL regime will deter or exacerbate violence.

33. Meernik, supra note 8 , at 180 . Meernik also states the need to unpack the "international community," for it is no "single actor with clear, consistent and readily identifiable interests." Id. at 179.

34. See supra note 31 and accompanying text.

35. Bosco, supra note 10, at 1. 
I. MiXING APPLES AND ORANGES? THE ICC AND THE CHALLENGE OF APPLYING DOMESTIC DETERRENCE THEORIES TO INTERNATIONAL LAW

"[I]t is virtually impossible to assess whether or not the threat of prosecution has ever prevented genocide and war crimes." - Miriam Aukerman ${ }^{36}$

In 1924, John H. Wigmore famously called deterrence " "the kingpin of the criminal law." ${ }^{\prime 37}$ It can be said that little has changed since then, as few legal scholars or professionals nowadays would downplay, let alone deny, the role of deterrence as one of the key purposes of criminal punishment. ${ }^{38}$ Since the publication and diffusion of seminal works by Thomas Hobbes ${ }^{39}$ Cesare Beccaria $^{40}$ and Jeremy Bentham ${ }^{41}$ legal theorists have focused exclusively on domestic criminal law and justice systems. ${ }^{42}$ Mullins and Rothe, for instance, argue that "[c]riminology in general has ignored international criminal law and international criminal justice; likewise, international criminal justice institutions and practitioners generally ignore criminological research." ${ }^{43}$ This might not have been a problem until the early 1990s, when the ICL regime project resumed, but it now begs the question of whether theories thought for and applied to domestic settings fit the international realm too. To be clear, criminologists are not the only scholars who overlook the salient

36. Rothe \& Schoultz, supra note 5, at 157 (quoting Miriam J. Aukerman, Extraordinary Evil, Ordinary Crime: A Framework for Understanding Transitional Justice, 15 Harv. Hum. RTS. J. 39, 66 (2002)).

37. Albert W. Alschuler, The Changing Purposes of Criminal Punishment: A Retrospective on the Past Century and Some Thoughts About the Next, 70 U. CHI. L. REV. 1, 4 (2003) (quoting A Symposium of Comments from the Legal Profession, 15 J. AM. INST. CRIM. L. \& CRIMINOLOGY 395, 401 (1924)) (internal quotation marks omitted).

38. On this point, see Alexander, supra note 6, at 2; Bosco, supra note 5, at 169.

39. See generally Thomas HobBes, Leviathan (Scolar Press 1969) (1651).

40. See generally Cesare Beccaria, On Crimes And Punishments (Seven Treasures Publications 2009) (1764).

41. See generally Jeremy Bentham, An Introduction to the Principles of Morals AND LEGISLATION (Prometheus Books 1988) (1789).

42. See Mullins \& Rothe, supra note 5, at 772.

43. Id. 
differences between domestic and international criminal law. Policymakers, professionals and scholars in the fields of law, sociology, psychology, and penology deserve to share the blame. Thus, in this Article I group together all extant deterrence theories inhabiting these disciplines under the broad umbrella of LDT. I do so consciously, as I hereby purport to show (1) the major limitations inherent in extant deterrence theories, (2) the improvements introduced by ICC norms and practices, (3) how teachings drawn from political science scholarship contribute to better theorize deterrence at the international level, and (4) how these teachings apply to the case study of Côte d'Ivoire. In this section, as said, I address the first and second points.

As earlier mentioned, LDT employs a set of assumptions that are useless for scholars who engage in the study of international law and politics in hopes of improving their understanding of how deterrence works at the international level. Proponents of deterrence maintain that individuals (or players in game-theoretic jargon) decide whether to obey or violate the law after striking a cost-benefit analysis of their actions. ${ }^{44}$ While this function of expected utility has been the cornerstone of LDT, early theories envisaged a role for emotions, in particular for instilling fear. ${ }^{45}$ Only at a later time did the rationality postulate tighten; fear was "rationalized" and reduced to the emotionless concept of cost. ${ }^{46}$ RDT rose to the forefront of academic debate, ${ }^{47}$ despite the efforts of

44. Such a course of reasoning, imbued with rationalist tenets, is what James March and Johan P. Olsen referred to as the "logic of consequences," in turn opposed to the norm-driven "logic of appropriateness." JAMES G. MARCH \& JOHAN P. Olsen, Rediscovering Institutions: The Organizational Basis of Politics 160-62 (1989); see also Kathryn Sikkink, The Justice Cascade: How Human Rights Prosecutions Are Changing World Politics 236 (2011). Somewhat similarly, Leslie Vinjamuri talks about "the triumph of consequences" in emphasizing that instrumental purposes of justice are replacing moral and legal ones in the mainstream narrative of advocacy organizations. Leslie Vinjamuri, Deterrence, Democracy, and the Pursuit of International Justice, 24 ETHICS \& INT'L AFF. 191, 198-201 (2010).

45. Ronald L. Akers, Rational Choice, Deterrence, and Social Learning Theory in Criminology: The Path Not Taken, 81 J. CRim. L. \& CRiminology 653, 660 (19901991).

46. For a critique, see infra, notes 47 and 48.

47. For information on RDT and its dominant-yet contested-role in the study of deterrence, see generally Robert Jervis, Deterrence Theory Revisited, 31 WORLD POL. 
proponents of cognitive psychology and social learning who pushed back against the rationality postulate. ${ }^{48}$ Yet criminal law, whether at the domestic or international level, resonates well with another postulate undergirding RDT. Rational choice, indeed, assumes that players hold perfect information of the payoff structure when making their decisions. ${ }^{49}$ Criminal law notably shifts the burden of knowledge on potential perpetrators. ${ }^{50}$ Thus, they must know which conduct is formally sanctioned and which is not, for ignorance of the law neither excuses nor mitigates criminal liability. In this regard, the high precision of the provisions envisaged in the Rome Statute allows future perpetrators to know beforehand what conduct substantiates the international crimes falling within the ICC jurisdiction. ${ }^{51}$

In the everlasting academic and policy debate on crime prevention, there is some agreement that three main factors (namely certainty, severity and celerity of punishment) jointly determine successful deterrence. ${ }^{52}$ Empirical research has established that certainty affects the above cost-benefit analysis more than considerations of severity or

289 (1979) [hereinafter Deterrence Theory Revisited]; Christopher H. Achen \& Duncan Snidal, Rational Deterrence Theory and Comparative Case Studies, 41 WORLD PoL. 143 (1989); Robert Jervis, Rational Deterrence: Theory and Evidence, 41 WorLd PoL. 183 (1989); Richard Ned Lebow \& Janice Gross Stein, Rational Deterrence Theory: I Think, Therefore I Deter, 41 World POL. 208 (1989); George W. Downs, The Rational Deterrence Debate, 41 WORLD POL. 225 (1989).

48. For materials in opposition to the "dominant" RDT, see generally Irving Piliavin et al., Crime, Deterrence, and Rational Choice, 51 Am. Soc. REv. 101 (1986); Ronald L. Akers, Rational Choice, Deterrence, and Social Learning Theory in Criminology: The Path Not Taken, 81 J. Crim. L. \& CRiminology 653 (1990); Daniel S. Nagin \& Greg Pogarsky, Integrating Celerity, Impulsivity, and Extralegal Sanction Threats into a Model of General Deterrence: Theory and Evidence, 39 CRIMINOLOGY 865 (2001).

49. For a critical view of applying the assumption of rationality to criminal behavior, see Akers, supra note 45, at 661-69.

50. Ignorantia juris non excusat, or ignorance of law excuses no one, a Latin maxim says.

51. For a discussion on precision as a dimension of the broader concept of legalization, see Kenneth W. Abbott et al., The Concept of Legalization, 54 I INT'L ORG. 401, 412-14 (2000).

52. Conversely, Kathryn Sikkink considers only certainty and severity, thus excluding the celerity factor. SIKKINK, supra note 44, at 170. 
celerity. ${ }^{53}$ This finding raises more questions than it answers. Certainty is used as an independent variable in this causal framework: the greater the certainty of punishment, the lower the crime rates. But certainty should in turn be conceived as a function of other factors, including the technology, material means, and intelligence available to law enforcement agencies, and the number of officers deployed within a given territory. This is tantamount to say that, all other things being equal, potential perpetrators are less likely to break the law where police forces are greater in number and better equipped, as these factors directly affect the probability of being caught and punished. Now, this line of reasoning does not and cannot apply at the international level, since the ICC was intentionally left without an autonomous enforcement agency and must rely on state cooperation. ${ }^{54}$ Thus, one of the domestic assumptions we must dismiss at the ICC level is the conflation between the threatener and the enforcer. Domestically, the state performs both roles. Laws prohibit certain conduct public prosecutors oversee investigations and press charges, courts try alleged perpetrators, and police forces enforce the laws and decisions issued by other state authorities. All these actors fulfill their duties in the name of and on behalf of the state and act under the umbrella of the state as the legitimate monopolist of violence. ${ }^{55}$ Unfortunately, this is not the case of the ICC.

Bearing in mind the three above-listed factors, the Assembly of State Parties can intervene on the institutional design of the Court to boost the severity factor; amendments to the Rome Statute can criminalize new

53. Mullins \& Rothe, supra note 5, at 773; see also Bruce Bueno de Mesquita \& Lawrence E. Cohen, Self-interest, Equity, and Crime Control: A Game-theoretic Analysis of Criminal Decision Making, 33 CRIMINOlogy 483, 487-88, 503 (1995); Daniel S. Nagin, Criminal Deterrence Research at the Outset of the Twenty-First Century, 23 Crime \& Just. 1, 2, 6-8 (1998); ANDrew von Hirsch ET Al., Criminal DeterRence and Sentence Severity: An Analysis of Recent Research 1-13 (1999); Bill McCarthy, New Economics of Sociological Criminology, 28 AnN. ReV. OF Soc. 417, 419-20 (2002).

54. The ICC is by no means the first international tribunal to face challenges related to the lack of enforcement powers. For a comparison with the ICTY, see HAGAN, supra note 9 , at $74,84,93,99$.

55. See supra note 24 and accompanying text. 
conduct or envisage harsher punishments for existing crimes. On celerity, the ICC can undertake to improve its current performance and make future trials quicker. Needless to say, the most salient problem facing the ICC is certainty. As enshrined in the Rome Statute, drafters decided to outsource law enforcement to states. ${ }^{56}$ In theory, state parties have a legal obligation to comply with ICC decisions and rulings, while non-state parties are under no such obligation unless the UN Security Council refers their domestic situation to the Court. ${ }^{57}$ In practice, however, even state parties have at times refused to cooperate with the Court. ${ }^{58}$ The explanation, I claim, is quite intuitive: compliance with ICC decisions has proven costly in both economic and political terms. The logic at play is similar to that of imposing multilateral sanctions on a third country; states may have a real interest in imposing sanctions, yet they wish other states will bear the costs of doing so. ${ }^{59}$ Put otherwise, the costs of imposing sanctions offset the interests of undertaking such a measure ${ }^{60}$ Thus, what is needed is (at least) one leading actor who can co-opt others to participate and, in case he or she fails to do so, acts unilaterally. As I demonstrate below, Côte d'Ivoire is a successful case mostly - albeit not exclusively - because of French political interference and military intervention in that country. I contend that, in this case, while ICC and UN officials routinely raised the specter of ICC

56. On state cooperation and related issues, see Valerie Oosterveld, Mike Perry \& John McManus, The Cooperation of States with the International Criminal Court, 25 FORDHAM INT'L L.J. 767, 767 (2001).

57. Id. at 770 .

58. For a list of episodes of non-compliance with ICC obligations, see Bosco, supra note 10 , at 158 .

59. On collective action problems in bearing the costs of global governance, see Ethan B. Kapstein, Power, Fairness, and the Global Economy, in POWER IN GLOBAL GOVERnANCE 88 (Michael Barnett \& Raymond Duvall eds., Cambridge University Press 2005).

60. For a better understanding of the logic underlying the imposition of sanctions on third parties, see Lisa L. Martin, Credibility, Costs, and Institutions: Cooperation on Economic Sanctions, 45 World PoL. 406, 413-16 (1993); William H. Kaempfer \& Anton D. Lowenberg, Unilateral versus Multilateral International Sanctions: A Public Choice Perspective, 43 InT'L STUD. Q. 37, 37-43, 46-51 (1999); Daniel W. Drezner, Bargaining, Enforcement, and Multilateral Sanctions: When is Cooperation Counterproductive?, 54 INT'L ORG. 73, 73-75 (2000). 
prosecution (i.e., the threateners), Ivorian leaders feared France (i.e., the enforcer) rather than the toothless Court in The Hague. ${ }^{61}$ In all, domestic LDT holds the state constant as the source of threat. At the international level, by contrast, it does not really matter who the threatener is; what does matter is remembering that while the enforcer can potentially vary every time, the threat of ICC prosecution is voiced.

There is a second - and specular-working assumption that ought to be dismissed when moving from domestic to international deterrence theories. All extant ICTs - and the ICC is no exception - target state and rebel senior leaders, that is, those who order, instigate or otherwise aid and abet the commission of atrocity crimes because of the position they hold along the command chain. ${ }^{62}$ To date, deterrence scholars have not

61. For a non-exhaustive list of threats of ICC prosecution voiced by UN or ICC officials, see Akhavan, supra note 13, at 639; McGovern, supra note 20, at 72; Scott Straus, 'It's Sheer Horror Here': Patterns of Violence During the First Four Months of Côte d'Ivoire's Post-Electoral Crisis, 110 AFr. AfF. 481, 483 (2011); Alex J. Bellamy \& Paul D. Williams, The New Politics of Protection? Côte d'Ivoire, Libya and the Responsibility to Protect, 87 InT'L AfF. 825, 833 (2011).

62. Historically, this "selection" process started off at Nuremberg and, except for the ICTY's early years, has remained valid through today. Charles C. Jalloh, Prosecuting Those Bearing "Greatest Responsibility": The Lessons of the Special Court for Sierra Leone, 96 MARQ. L. REV. 863, 872 (2013). The formulas ICTs have employed to justify the choice of who is worth prosecuting are intentionally vague and ill defined. See id. at 872-80. The Special Court for Sierra Leone, for instance, is granted "the power to prosecute persons who bear the greatest responsibility for serious violations of international humanitarian law and Sierra Leonean law." Agreement between the United Nations and the Government of Sierra Leone on the establishment of a Special Court for Sierra Leone, art. 1, ๆ 1, Jan. 16, 2002, 2178 U.N.T.S. 145. Similarly, the Nuremberg and Tokyo trials sought to bring to justice " major war criminals," identified as those who led, organized, instigated, or conspired to commit any of the crimes envisaged by their charters. Jalloh, supra note 62, at 873 (citing Charter of the International Military Tribunal art. 1, Aug. 8, 1945, 59 Stat. 1544, 82 U.N.T.S. 279; International Military Tribunal for the Far East art. 1, Jan. 19, 1946, 4 U.S.T. 20). Lastly, despite not setting forward explicit criteria for personal jurisdiction, it is also fair to state that the ICC is interested in targeting only those bearing the greatest responsibility for the commission of international crimes. Id . at 879 . Empirical evidence of who has actually been prosecuted by ICTs strongly supports the claim that international prosecution is reserved to highprofile perpetrators. $I d$. at 889 . Mass atrocities require planning, and only those at the top of the command chain can deliver well-crafted plans and provide the leadership necessary to carry them out. Id. As Charles Jalloh underscores, this ongoing "selection practice" 
paid due attention to the selection ratione personae operated by the ICTs. ${ }^{63}$ Yet confusing senior political or military leaders with average citizens is likely to hamper understandings of deterrent mechanisms internationally. On this point, a significant improvement in the scholarly debate followed the work on social position. ${ }^{64}$ Sociologists and criminologists successfully tested a fairly intuitive hypothesis, according to which "those in positions with more at stake to risk are more likely to desist and or refrain from crime." ${ }^{\prime 65}$ A related improvement in the field is the increasing attention now paid to non-legal sanctions; ${ }^{66}$ social sanctions can alter the risk calculus. ${ }^{67}$ Decision-makers in both the private and public sectors do (and should) take into account reputational concerns affecting themselves at the personal or organizational level.

In turn, these findings raise a number of new interesting questions for scholars of international law and politics-questions that this Article seeks to engage. First, do social sanctions affect the time-horizon of potential high-level offenders? It is possible to claim that social sanctions follow the arrest, not the conviction, and thus apply sooner than legal

entails "that the middle and lower ranking suspects would be investigated and prosecuted in domestic courts." Id. at 872 . Writing about the investigation that eventually led to the trial of General Radislav Krstić before the ICTY, John Hagan duly emphasized that "the events at Srebrenica were planned and highly organized in ways reflective of systematic genocide." HAGAN, supra note 9, at 157. In conclusion, both analytical reasoning and empirical evidence suggest that elite involvement, often revealed through the position held along the chain of command, amounts to a necessary condition for ICC prosecution.

63. On this point, Akers correctly points out that "[d]eterrence locates variation of criminal behavior in only one part (direct positive punishment of criminal behavior) of one side of the overall reinforcement equation, albeit including the three modalities of certainty, severity, and celerity." Akers, supra note 45, at 660. It follows that all "players" are assumed to act alike regardless of their social position.

64. See Kim \& Sikkink, supra note 31, at 945, 959.

65. Rothe \& Schoultz, supra note 5, at 156; see also Mullins \& Rothe, supra note 5 , at 774 .

66. In this regard, it bears underscoring that Hun Joon Kim and Kathryn Sikkink are, to the author's knowledge, the first political scientists to carry out a quantitative analysis on the deterrent effects of human rights prosecution (which is a super-set of prosecutions before ICTs). See generally Kim \& Sikkink, supra note 31.

67. Id. at 945. For clarity's sake, this Article distinguishes between formal (or legal) (e.g., years in prison or the amount of reparations) and social sanctions (e.g., social disapproval, calls for resignation). 
sanctions. Second, what are the effects of "raising the stakes" for individuals confronting the above-said risk calculus? Arguing that it is merely a matter of increasing positive and negative payoffs risks oversimplifies the complexity of the underlying decision-making processes. Indeed, working on the payoff structure can do more than just reordering individual preferences; it can also lead to situations whereby actors have either no interest in ceasing their criminal activities or even an increasing advantage in exacerbating violence ${ }^{68}$ It is therefore crucial to explore how the Rome Statute, along with the other norms and procedures governing the ICC, has amended the legal structure and, in turn, individual choices on compliance.

The third major problem characterizing LDTs is the timing of their application. Both general deterrence and specific deterrence theories start with the factual premise that a crime has occurred. ${ }^{69}$ Mainstream legal scholarship defines general deterrence as "the inhibiting effect of sanctions on the criminal activity of people other than the sanctioned offender," "70 while specific deterrence "refers to the discouragement of subsequent criminal activity by those who have been punished." $"$ For restrictive deterrence, future perpetrators look at - and learn from-past crimes in order to minimize the severity of legal punishment. ${ }^{72} \mathrm{~A}$

68. A somewhat similar point is raised in Rothe \& Schoultz, supra note 5, at 156. For a study of the evolving nature of violence in modern warfare, from military instrument to self-serving objective, see MARY KALDOR, NEW AND OLD WARS: ORGANized ViOlenCe IN A Global ERA (3rd ed. 2012). For a critique of the current, static legal regime applied to evolving methods and means of warfare, see Nicolas Lamp, Conceptions of War and Paradigms of Compliance: The 'New War' Challenge to International Humanitarian Law, 16 J. ConfLICT \& SEC. L. 225 (2011).

69. For a review of classical deterrence theories and how they apply to international justice, see Alexander, supra note 6; Bosco, supra note 5; Cronin-Furman, supra note 12.

70. Kim \& Sikkink, supra note 31, at 943 (quoting DETERRENCE AND InCAPACitATion: Estimating the EFFECTS of CRiminal SANCTIONS ON CRime RATE (Alfred Blumstein et al. eds., National Academy Press 1978) (emphasis added)).

71. Bosco, supra note 5, at 170 (emphasis added).

72. Restrictive deterrence has occurred "when, to diminish the risk or severity of a legal punishment, a potential offender engages in some action that has the effect of reducing his or her commissions of a crime." Bosco, supra note 5, at 171 (quoting Jack P. Gibbs, Deterrence Theory and Research, in THE LAW AS A BEHAVIORAL Instrument: 
feedback loop is at play in the latter: past crimes inspire new laws, and these laws in turn inform the ways and means by which criminals commit future crimes. ${ }^{73}$ Finally, past crimes are integral to the method of rational choice in that they provide the raw data upon which potential perpetrators compute the probability of being caught and punished. That said, international crimes are not ordinary crimes. The grave, widespread and systematic nature of the former is such that it would be preferable to build on theories that do not require previous crimes of the same kind. In the end, the overall epistemological objective is to think international legal deterrence anew. Building on international relations scholarship, the new task of LDT must be the avoidance of mass atrocities in the first place rather than to disincentivize its repetition.

\section{A. The ICC and its Deterrent Impact: Game Changer or House of Cards?}

Unsurprisingly, the idea of establishing the first permanent criminal court garnered sizable attention and consensus in both scholarly and policy fora well before the court came into being. By the time the Rome Statute reached its sixtieth ratification on April 11, 2002, the soon-to-be ICC was already portrayed as a game changer. ${ }^{74}$ The official narrative maintained that drafters designed the ICC to end impunity globally. ${ }^{75}$ Lofty rhetoric notwithstanding, scholars disagreed - and still disagree, albeit to a lesser extent - as to whether the ICC does have such a deterrent impact and can therefore fulfill its mission. ${ }^{76}$ This Article maintains that the ICC has remarkably improved the deterrent impact of

Nebraska Symposium on Motivation 87-88 (Gary B. Melton ed., Univ. of Neb. Press 1986)).

73. For a historical account of the above-mentioned feedback loop between law and crime, see generally John Hagan. Who Are the Criminals?: The Politics of Crime Policy from the Age of Roosevelt to the Age of Reagan (Princeton University Press, 2010).

74. See John Washburn, The Negotiation of the Rome Statute for the International Criminal Court and International Lawmaking in the 21st Century, 11 PACE INT'L L. REV. 361, 361-62 (1999); BosCO, supra note 10, at 2-4.

75. Bosco, supra note 10 , at 3.

76. See supra note 3 and accompany text. 
the ICL regime, and yet it is still insufficient to secure compliance with the norms its statute enshrines, let alone to coerce violators into compliance in situations of ongoing conflict. That said, this shortcoming is not an unfortunate or unforeseen side effect of how ICC operations eventually unfolded; the ICC was designed to have a limited deterrent impact. ${ }^{77}$ As already pointed out, the Rome Statute outsourced the certainty factor to states. ${ }^{78}$ Put otherwise, the key factor of a credible threat of punishment is exogenous to the ICC. Legal obligation notwithstanding, actual state cooperation with the Court hinges on political considerations. ${ }^{79}$

Historically, it bears recalling that questions about the relationship between international prosecutions and the actual deterrence of future atrocities long predate the establishment of the ICC. From a brief survey of the field, there is no clear agreement as to whether or not ICTs have deterred or can deter further atrocities. Julian $\mathrm{Ku}$ and Jide Nzelibe conclude their large-N quantitative analysis of coup plotter casualties in Africa by suggesting that ICTs have no significant deterrent effects on future violence. ${ }^{80}$ According to Charles Villa-Vicencio, achieving peace does not necessarily require pursuing criminal prosecution for perpetrators; not only are other policy and legal options available, but in certain cases, prosecution may even undermine political efforts undertaken in hopes of ending violence. ${ }^{81}$ Linda Keller stresses the importance of considering justice mechanisms alternative to international prosecution, including non-prosecutorial options. ${ }^{82}$ Relatedly, upon

77. On the limits of the ICC's institutional design, see Bosco, supra note 5, at 173.

78. See supra pp. $367-68$, note 56 , and accompanying text.

79. Sharing the concern that state compliance may hinge upon political convenience, see, inter alios, Paola Gaeta, Is the Practice of 'Self-Referrals' a Sound Start for the ICC?, 2 J. INT'L CRIM. JUST. 949, 951-52 (2004). For an example of state authorities using the ICC instrumentally, see Sarah M.H. Nouwen and Wouter G. Werner, Doing Justice to the Political: The International Criminal Court in Uganda and Sudan, 21 EuR. J. OF INT'L L. 941, 949 (2010).

80. Ku \& Nzelibe, supra note 3, at 831-32.

81. Charles Villa-Vicencio, Why Perpetrators Should Not Always Be Prosecuted: Where the International Criminal Court and Truth Commissions Meet, 49 EMORY L.J. 205, 209 (2000).

82. Keller, supra note 27, at 210-11. 
examining thirty-two civil conflicts and how they eventually came to an end, Jack Snyder and Leslie Vinjamuri found that "successful" postconflict stories more often than not envisaged amnesties for past abusers; with specific regard to criminal prosecutions, they emphasized the importance of institutional capacity in explaining successes and failures of criminal prosecutions across cases. ${ }^{83}$ In separate articles, Diba Majzub and James Meernik challenge the normatively appealing assumption that peace and justice can be achieved together, questioning whether it is correct to conceive the latter as a necessary condition of the former. ${ }^{84}$ David Wippman is agnostic on whether ICTs exert deterrent effects onto potential criminals. ${ }^{85}$ On one hand, he laments that deterrence "is at best a plausible but largely untested assumption"; 86 on the other hand, he concludes that "the general deterrent effect of [international] prosecutions seems likely to be modest and incremental, rather than dramatic and transformative." 87 Theodor Meron and Payam Akhavan shared Wippman's view that more empirical evidence is still needed before claims about deterrence can be trusted. ${ }^{88}$ Finally, Hun Joon Kim and Kathryn Sikkink found support for the claim that human rights prosecutions (a superset of international prosecution) hold deterrence effects across borders. ${ }^{89}$

Proponents of deterrence through international prosecutions are somewhat more optimistic when discussing the ICC as opposed to ICTs altogether. Through a more refined literature review, I identified four macro categories of arguments scholars and professionals use to support

83. Jack L. Snyder \& Leslie Vinjamuri, Trials and Errors: Principles and Pragmatism in Strategies of International Justice, INT'L SEC. Winter 2003/04, at 5, 18 20, 25.

84. Diba Majzub, Peace or Justice? Amnesties and the International Criminal Court, 3 MelB. J. InT'L L. 247, 248-49 (2002); James Meernik, Justice and Peace? How the International Criminal Tribunal Affects Societal Peace in Bosnia, 42 J. of PeACE Res. 271, 271-73 (2005).

85. Wippman, supra note 1 , at 474 .

86. Id.

87. Id. at 488 .

88. Theodor Meron, From Nuremberg to the Hague, 149 MiL. L. REv. 107, 110 (1995); Akhavan, supra note 12, at 744.

89. Kim \& Sikkink, supra note 31, at 939. 
their claims. First, drafters have purposely conveyed much of the experience and jurisprudence developed by other ICTs into the Rome Statute..$^{90}$ Put otherwise, the Rome Statute was instrumental in codifying many legal and jurisprudential novelties previously adopted in the statutes and case law of other ICTs. In so doing, the Rome Statute became the key tool for enhancing consistency in the application of ICL across cases and over time. ${ }^{91}$ Drafters took another bold decision for the sake of consistency during negotiations, as they forbade reservations to the treaty. ${ }^{92}$ Candidates for membership confront the sheer choice of either becoming a party or not. Relatedly, prohibiting reservations entails that, unlike in most other multilateral treaties, all state parties carry equal legal obligations. Crafting the Rome Statute in such a way has had two main consequences. Politically, the enterprise of establishing the first permanent ICT brought about radical change in the leadership of the overall ICL project. ${ }^{93}$ The United States, whose patronage was critical to kicking off the two ad hoc tribunals just a few years earlier, never concealed its aversion to a number of provisions that nonetheless made the final draft. ${ }^{94}$ The United Kingdom and France took over the role of ICL "champions" at the global level. ${ }^{95}$ Ratification of the Rome Statute has become the main proxy used to gauge state commitment to the ICL

90. See Washburn, supra note 74, at 365.

91. For a similar concern (but expressed from a different perspective), see Avril McDonald, Sierra Leone's Shoestring Special Court, 84 InT'L REV. OF THE RED Cross 121, 137 (2002).

92. "[N]o reservations are allowed (Article 120), but a state party may opt out of the provision giving the ICC jurisdiction over war crimes for a period of seven years (Article 124)." Mahnoush H. Arsanjani, The Rome Statute of the International Criminal Court, 93 AM. J. INT'L L. 22, 41-42 (1999).

93. Bosco, supra note 10, at 43-44.

94. For a discussion on claims to American exceptionalism vis-à-vis the ICL regime, see HAGAN, supra note 9, at 96, 206; MARK MAZOWER, GOVERNING THE WORLD: THE HISTORY OF AN IDEA 400-01, 404 (2012).

95. BosCO, supra note 10, at 43-44. Regarding the notion of "champion," I use it as a synonym for John Hagan's notion of "hero." HAGAN, supra note 9, at 106. Hagan puts forward a sociological explanation whereby different actors (states, in this case) compete for the status of "hero." Id. This status is bestowed upon the moral agent "who will bear the potential risk costs ... to undertake the idealized behavior that may result in obtaining the status of "hero." Id. 
regime. ${ }^{96}$ The second consequence directly concerns the deterrent impact of the ICC. A Latin maxim says: Nullum crimen sine praevia lege. For the fear of punishment to deter crimes, the logical and temporal premise is that potential perpetrators know beforehand which conduct is forbidden and which the law permits. Clarity in the law is thus a necessary precondition for legal deterrence to work properly. ${ }^{97}$

Clarity in the law is intimately intertwined with both the second and third broad arguments topics researchers point to when claiming that the ICC has improved the chances of legal deterrence at the international level: ICC's temporal and territorial jurisdiction. Unlike other ICTs (including the two ad hoc tribunals, the Special Court for Sierra Leone and the Special Tribunal for Lebanon, and the Extraordinary Chambers in the Courts of Cambodia), the ICC is mandated to investigate and try crimes that have occurred since its entry into force. ${ }^{98}$ On this point, Eamon Aloyo, Yvonne Dutton, and Lindsay Heger hold that " $[\mathrm{t}]$ he ad hoc tribunals have no such general forward-looking deterrent effect: although there may have been a limited deterrent effect with the ICTY, they were created after atrocities began and their jurisdiction is limited to dealing with those." ${ }^{\text {999 }}$ Likewise, Kate Cronin-Furman maintains that, by virtue of its "potentially unlimited geographic . . . and prospective temporal jurisdiction," the ICC "represents the most likely institution for triggering a deterrent effect." 100 In all, there is strong consensus on the proposition that ICC's jurisdiction enhances the chances for legal deterrence to constrain criminal behavior and thus prevent atrocities.

But the ICC has accomplished far more than simply collecting and enshrining a broad array of legal norms and customs into a single document. The fourth and last category of arguments about the ICC's

96. See, e.g., Beth A. Simmons \& Allison Danner, Credible Commitments and the International Criminal Court, 64 INT'L ORG. 225, 234 (2010).

97. For a discussion on the increased clarity in the ICL regime as a result of the Rome Statute, see SiKKINK, supra note 44, at 97, 199.

98. Eamon Aloyo et al., Does the International Criminal Court Deter Torture? 7-8 (March 27, 2013) (unpublished draft manuscript) (on file with One Earth Future Foundation), available at http://oneearthfuture.org/sites/oneearthfuture.org/files// documents/publications/ICC-and-Torture_working-paper.pdf.

99. Id. at 8 (emphasis added); see also Alexander, supra note 6 , at 3 .

100. Cronin-Furman, supra note 12, at 441. 
enhanced deterrent potential groups together studies of both the legal novelties introduced in the Rome Statute and their spillover effects on the relations between the Court and state parties. ${ }^{101}$ The common denominator of these studies is the unprecedented (legal and political) flexibility bestowed upon the ICC, in particular, the discretion managed by the Office of the Prosecutor (OTP). ${ }^{102}$ As I demonstrate below, this flexibility is at once the key to overcoming limits inherent to LDT and the reason for which ICC experts should draw on international relations (IR) theory for guidance on how to actually put it to use. Domestically, researchers face at least two intertwined problems. First, the logic of deterrence dictates a dichotomous categorization of human behaviors. One action is either lawful or not; there can be no intermediate ground between these two opposites. Second, it is possible to tell only when deterrence fails, while compliance does not afford observers to set forth causal claims on the inhibiting power of sanctions. Internationally, the Rome Statute envisages the "gravity threshold," 103 which categorizes criminal activity along a continuum: from unworthy to worthy of international judicial scrutiny. ${ }^{104}$ This change in categorization has

101. See infra note 103 and accompanying text.

102. See infra, note 103 and accompanying text.

103. See Kevin Jon Heller, Situational Gravity Under the Rome Statute, in FuturE Perspectives on International Criminal Justice 32, 34 (Carsten Stahn \& Larissa van den Herik eds., 2010); Susana SáCouto \& Katherine Cleary, The Gravity Threshold of the International Criminal Court, 23 AM. U. INT'L L. REV. 807, 811 (2008); Wasana Punyasena, Conflict Prevention and the International Criminal Court: Deterrence in a Changing World, 14 Mich. St. J. InT'L L. 39, 50 (2006); Mohamed M. El Zeidy, The Gravity Threshold Under the Statute of the International Criminal Court, 19 CRIM. L.F. 35, 45-50 (2008). In all, prosecutorial discretion at the ICC level pivots on two illdefined notions, namely the "interest of justice" and the "gravity threshold." SáCouto \& Cleary, supra at 808. At first glance, the latter is to be regarded as an indicator of the former. Put otherwise, if the gravity threshold is met, then it is in the interest of justice to investigate that case. For an in-depth analysis of the relationship between the "interests of justice" and the "gravity threshold." See Darryl Robinson, Serving the Interests of Justice: Amnesties, Truth Commissions and the International Criminal Court, 14 Eur. J. OF INT'L L. 481, 481-93 (2003); Akhavan, supra note 13, at 633 n.19.

104. The gravity threshold is a multifaceted concept that entails - but is by no means limited to - considerations on the quantity of violence already perpetrated at any time during an ongoing conflict and/or episode of mass violence. That being said, the 
created a grey zone - no matter how narrowly or broadly conceivedwhere the OTP can intervene in order to prevent the escalation, rather than the commission, of atrocities. ${ }^{105}$ On the issue of causality, the mere existence of the sanctioning regime set forth in the Rome Statute has enabled researchers to distinguish between decisions driven by normative concerns and rationalist calculations of expected utility. ${ }^{106}$ Relatedly, the ICC's legal flexibility affords a practical expedient to observe the deterrent effects of threats on compliance, thus overcoming Nick Grono's concerns on the empirical limitations of testing LDT. ${ }^{107}$ The idea is to examine cases wherein the underlying offense or conduct is negative. ${ }^{108}$ For the purpose of this Article, an offense or conduct is negative when the perpetrator has already undertaken illicit action at the time the threat of prosecution intervenes, and following which he must stop in order to avoid sanctions. A recurring example in ICL case law is the instigation to commit atrocities. ${ }^{109}$

quantum of violence tolerated is the most salient aspect for the argument set forth in this Article.

105. See generally Akhavan, supra note 13, at 633. See also Song, supra note 7, at 207-08.

106. Aloyo et al., supra note 98, at 7-8, 14. Here the authors found that state parties to the Rome Statute are less likely to commit torture than states that have ratified the Convention Against Torture (CAT) but not the Rome Statute. Id. at 6. This finding, they argue, is due to the fact that, while both treaties forbid torture, the CAT does not provide for criminal sanctions, whereas the Rome Statute does. Id. at 13-14.

107. Nick Grono, The Deterrent Effect of the ICC on the Commission of International Crimes by Government Leaders, INT'L CRISIS GRP. (Oct. 5, 2012),

http://www.crisisgroup.org/en/publication-type/speeches/2012/grono-the-deterrent-effectof-the-icc.aspx.

108. This practical expedient is meant to address the methodological concerns of maximizing concreteness. According to Gary King, Robert Keohane, and Sidney Verba, "[w] should choose observable, rather than unobservable, concepts whenever possible. . . . [For the latter] can be a hindrance to empirical evaluation of theories and hypotheses." Gary King et AL., Designing Social InQuiry: Scientific InfERence in Qualitative RESEARCH 109 (1994).

109. In the case of Côte d'Ivoire, the main-albeit not the exclusive-conduct examined is instigation (or incitement) to commit atrocities through state-owned or statecontrolled media by senior political leaders. On this point, see Straus, supra note 61, at 484. Choosing instigation to commit atrocities offers another advantage, as it allows comparative analysis across cases and over time. Indeed, other cases of instigation to commit atrocities include Rwanda, the Democratic Republic of the Congo, and more 
Unsurprisingly, the number of researchers deserving membership in this fourth category has increased dramatically over the past few years. Moreover, the debate on the ICC deterrent impact is not exclusively for scholars; former and current professionals actively participate therein, bringing in valuable insight on the Court's internal dynamics and operations. Wasana Punyasena and Payam Akhavan, for instance, are among those who have stressed the legal novelties introduced by the Rome Statute, and how these in turn enhance the ICC deterrent impact. ${ }^{110}$ Song, as said earlier, argues that the ICC preventive potential is by no means limited to deterring future crimes. ${ }^{111}$ In his account, the threat of ICC prosecution also affects short-term decision-making processes. ${ }^{112}$ Public statements, arrest warrants and formal indictments issued by the OTP have the potential to dissuade potential criminals from engaging in imminent unlawful behavior. ${ }^{113}$ These authors correctly agree and insist that the ICC has a specific role to play in ongoing conflicts. According to them, the ICC should work toward preventing the escalation of atrocities within the broader conflict setting. ${ }^{114}$ What these authors lack, I claim, is a theoretical framework on which to apply the novelties envisaged by in the Rome Statute and the following practices developed by the OTP. Thence stems the need for importing the concept of immediate deterrence into the legal debate.

Other authors interestingly investigate the relations between the ICC and state parties. Fully aware that the Court lacks teeth to enforce its own decisions, their work aims to shift the burden of apprehending and trying suspects onto domestic actors. On one hand, their understanding of ICC-

recently Kenya. See generally Gregory S. Gordon, Formulating a New Atrocity Speech Offense: Incitement to Commit War Crimes, 43 LOY. U. CHI. L.J. 281 (2012). For a more critical view of the role played by the media in inciting atrocity crimes, see generally Scott Straus, What Is the Relationship between Hate Radio and Violence? Rethinking Rwanda's "Radio Machete", 35 POL. \& Soc'y 609 (2007).

110. Punyasena, supra note 103, at 68-69. See generally Akhavan, supra note 13.

111. Song, supra note 7, at 207-08.

112. Id. at 208 .

113. Id.; see also Bosco, supra note 5, at 181.

114. On the ICC's ambitious role in conflict prevention and management, see generally Akhavan, supra note 13; Song, supra note 7; Punyasena, supra note 103; Vinjamuri, supra note 44. 
state parties relations is wedded to a traditional principal-agent logic; on the other hand, they switch the Court's position, making it an agent instrumental to the successful domestic prosecution of international crimes. Since these scholarly accounts build on the same cornerstone, i.e., the principle of complementarity, the most salient difference among them lies in whether ICC and state interests converge or not. Anne-Marie Slaughter and William Burke-White reject the traditional distinction between international and domestic law as outdated. ${ }^{115}$ According to them, it is no longer possible to consider these two sets of rules to be disconnected. ${ }^{116}$ International law, in particular, "has penetrated the once exclusive zone of domestic affairs to regulate the relationships between governments and their own citizens, particularly through the growing bodies of human rights law and international criminal law." 117 Within this ongoing process of reshaping the boundaries between international and domestic law, Burke-White advocates for what he calls "proactive complementarity." "Not only does the ICC defer to state jurisdiction, but it could also "encourage and at times assist states in undertaking domestic prosecutions of international crimes." 119 Complementarity can also be used when ICC and state interests diverge at the outset. James Alexander's notion of "complementary deterrence" is meant to pressure state authorities to fulfill their obligations under the Rome Statute. ${ }^{120}$ The logic at play is that the OTP observes what action governments take domestically and, if state response does not meet international standards of justice, invokes the complementarity principle, and summons the investigation to The Hague. Through this mechanism, Alexander

115. Anne-Marie Slaughter \& William Burke-White, The Future of International Law Is Domestic (or, the European Way of Law), 47 HARV. InT'L L.J. 327, 327 (2006).

116. Id.

117. Id.

118. William W. Burke-White, Proactive Complementarity: The International Criminal Court and National Courts in the Rome System of International Justice, 49 HARV. INT'L L.J. 53, 54 (2008) (emphasis added).

119. Id. at 53.

120. Alexander, supra note 6, at 20-22. 
contends, "the ICC can exert leverage over governments that might otherwise fail to investigate or prosecute grave crimes." ${ }^{121}$

All in all, the establishment and entry into force of the ICC represented a watershed moment for the international criminal justice system as a whole. As so many authors have pointed out, the threat of ICC prosecution has the potential to affect individual decision-making processes. Potential perpetrators should know that certain conducts are no longer tolerated and, if they decide to ignore ICC provisions, they face the risk of prosecution before it. ICC's temporal and territorial jurisdiction amounts to a necessary precondition for potential criminals to perceive the threat of punishment. Additionally, the ICC can intervene in ongoing conflicts and prevent the escalation of violence, although it is not yet clear what strategy the Court should adopt to succeed in this task. ${ }^{122}$ ICC's enhanced deterrent impact is a function of its greater legal and political flexibility vis-à-vis other ICTs. ${ }^{123}$ The gravity threshold and interest of justice norms enable the OTP to escape the rigid logic of RDT and adjust ICC response to the level of violence unleashed. ${ }^{124}$ Relatedly, the OTP has developed internal strategies on how to liaise with national governments for the aim of spawning (or, if necessary, soliciting) cooperation by the latter. ${ }^{125}$ These improvements notwithstanding, it would be mistaken to forget that the Rome Statute has outsourced enforcement to state actors. Lacking teeth to enforce its own decisions,

121. Id. A good first case for testing Alexander's argument might be Guinea. Unlike in Côte d'Ivoire, Guinean state authorities announced their willingness to work along with the Court and carry out genuine investigations (and eventually prosecutions) against those who committed, ordered or anyhow aided and abetted the perpetration of violence against civilians in the fall of 2009. Id. Criminal liability of members of the military junta ruling the country is very likely, if not certain. Id. One possible (political) explanation as to why Guinean state authorities have agreed to cooperate with the ICC is that the potential enforcer is - as in Côte d'Ivoire-France. See id.

122. See Song, supra note 7, at 208.

123. See generally supra note 103 and accompanying text.

124. See supra note 103 and accompanying text.

125. For example, see Paper on Some Policy Issues before the Office of the Prosecutor, ICC-OTP, 2, 8 (Sept. 2003), available at https://www.icc-cpi.int/NR/ rdonlyres/1FA7C4C6-DE5F-42B7-8B25-60AA962ED8B6/143594/030905_Policy_ Paper.pdf. 
the ICC has virtually no means to improve the certainty factor and, in turn, the deterrent impact of threatening international sanctions.

\section{ARMING THE THREAT OF CRIMINAL SANCTIONS: LESSONS ON DETERRENCE FROM INTERNATIONAL RELATIONS (IR) THEORY.}

"The principle of deterrence is as old as history." - Henry Trofimenko ${ }^{126}$

"Deterrence theory. . . is probably the most influential school of thought in the American study of international relations." - Robert Jervis ${ }^{127}$

I have heretofore argued that domestic LDTs are ill equipped to explain what determines whether or not the ICC will deter potential criminals. Their main flaw, I claim, is that they overlook, if not completely ignore, the coercion lying at the core of any threats. Yet law scholars have long noticed that "[i]t is the credible threat of the use of force that becomes the primary weapon in deterrence theory." ${ }^{28}$ Even Rudolph, an author whose scholarship reaches across disciplines, points at IR theory when listing the ingredients for deterrence to work effectively. ${ }^{129}$ As a result, one of the purposes of this section is to bring considerations of power back in. ${ }^{130}$ But reintroducing the coercive aspect of deterrence theory is still insufficient. As for the broader concept of power, deterrence is also relational. Domestically, deterrence runs

126. Henry Trofimenko, Changing Attitudes Toward Deterrence, in NATIONAL SECURITY AND INTERNATIONAL STABILITY 65, 65 (Bernard Brodie et al. eds., 1983).

127. Deterrence Theory Revisited, supra note 47, at 289.

128. Smidt, supra note 3, at 167.

129. According to Christopher Rudolph, "[e]ffective deterrence requires three elements - commitment, capability and credibility." Rudolph, supra note 17, at 684 .

130. Adapting Robert Dahl's famous definition of power, deterrence can be considered the negative face of the same capacity by which A gets B to do something B would otherwise not do. Robert A. Dahl, The Concept of Power, 2 BeHAV. SCI. 201, 202 (1957). Similarly, Thomas Schelling conceptualizes coercion as a category including its two specular faces, namely compellence and deterrence. ThOMAS C. Schelling, ARMS AND INFLUENCE 69-78 (1966). 
between the state and the individual perpetrator, with the state performing the dual role of threatener and enforcer. At the international level, however, the ICC threatens only, while a state (or a coalition of states) acts as enforcer. Thus, it is necessary to pay due attention to the enforcer, that is, to the actor who is the protagonist of this coercive relation.

All that said, this section is organized as follows. First, I introduce the notions of immediate and extended deterrence, and I explain why these further our understanding of the ICC's preventive potential. Next, I argue why the assumption of perfect information made by RDT must be relaxed; the threat of ICC prosecution should be interpreted a signal and, as such, it must be clearly sent and correctly decoded in order to convey its message. Third, I lay out a typology of the strategies that states fallen under ICC scrutiny can adopt. Lastly, I advocate for a better understanding of African politics. To date, there is in fact no correlation between the attention paid to the African continent by the ICC and the knowledge of power dynamics therein. With eight countries under investigation and two more preliminary examinations waiting, it is about time that the ICC-and the OTP in particular-sharpens its comprehension of how politics is carried out in Africa.

\section{A. New Concepts for Old Theories: Immediate and Extended Deterrence}

Deterrence theory is by definition a terrain for academic crossfertilization. I already pointed out that no discipline can claim exclusive ownership of deterrence, for scholars from different social sciences have contributed to its study. Against this backdrop, it is somewhat puzzling to understand why political science scholarship on deterrence stands alone within the broader scholarly debate. At a glance, it might be a "problem" of different units of analysis; LDT looks at individuals, whereas IR theory focuses on states. However, this argument shall be cast aside, as the field of ICL offers a unique opportunity to bring together these two scholarships. What is needed, I contend, is a hybrid theoretical framework that incorporates both units of the analysis so as to apply to one specific category of subjects: domestic decision-makers. The underlying logic pivots on the Janus-faced nature of these subjects, 
who can be threatened of individual sanctions in order to forestall decisions that affect society as a whole. Thus, the chosen unit of analysis is different from IR theory in that responsibility for collective action is now individualized, while beforehand there was no assumption that decision-makers had to suffer personally from the consequences of their decisions. Likewise, the same unit of analysis differs from LDT in that, unlike the average citizen, domestic decision-makers have a collective dimension by virtue of their position within civilian or military bureaucracies. That said, the establishment of the ICC calls for further adaptation of this hybrid framework. There are two concepts that I deem worth importing from IR theory into the study of ICC's preventive impact. The first is immediate deterrence, ${ }^{131}$ which resonates well with the gravity threshold principle envisaged by the Rome Statute and can potentially inform OTP strategies aimed at preventing the escalation of violence. The second is extended deterrence, ${ }^{132}$ which applies to the distinction between threatener and enforcer that I set forth.

Legal scholars such as Song and Akhavan argue that the threat of ICC prosecution can prevent-and has prevented-domestic actors from escalating violence into mass murder. ${ }^{133}$ Similarly, David Bosco discusses the OTP's strategy to "prevent . . . violent scenario[s] from occurring through public statements and warnings directed at political or ethnic leaders." 134 From these accounts stems the need for a theory linking up ICC provisions and practices. I propose a framework whereby the gravity threshold provides the OTP with a temporal window for intervention - a temporal window running from no violence at all until the gravity threshold is finally met. OTP intervention can take many forms, including public statements, indictments, and arrest warrants. This is not to say that OTP response is random; as violence increases, so does OTP response. The underlying logic — which is not new to IR theory-is

131. On the concept of immediate deterrence, see generally Paul K. Huth, Reputations and Deterrence: A Theoretical and Empirical Assessment, 7 SEC. Stud. 72 (1997).

132. On the concept of extended deterrence, see generally PAUL K. Huth, EXtended DeterRence AND the Prevention of WAR (1991).

133. Song, supra note 7, at 207-08; Akhavan, supra note 13, at 625, 636.

134. Bosco, supra note 5, at 171. 
to match the level of violence with the severity of threat. ${ }^{135}$ Immediate deterrence hereby represents the causal mechanism connecting the violence perpetrated at any given moment to OTP response within the limited temporal window afforded by the gravity threshold. On this point, it is worth noting that political scientists conceive immediate deterrence as the alternative to general deterrence. ${ }^{136}$ In Paul Huth's words, "[g]eneral deterrence refers to a policy which seeks to prevent a state from issuing a military threat to change the status quo, while immediate deterrence refers to a policy which attempts to prevent a state, which has already threatened force, from initiating the large-scale use of force." ${ }^{137}$ Put otherwise, the latter applies to existing crises, while the former does not. ${ }^{138}$ For both political scientists and legal scholars, general deterrence is characterized by logical (and legal) rigidity, which justifies the dichotomous coding of human deeds into either lawful or unlawful. In conclusion, immediate deterrence amounts to a causal framework that accommodates - and even endorses-ICC legal flexibility, while general deterrence is not engineered to do likewise.

The second concept worth importing from IR theory is that of extended deterrence. Political scientists describe it as a situation wherein "one major power (defender) attempts to deter another (challenger) from starting or continuing a conflict involving a third party (protégé)." ${ }^{139}$ This

135. David Gompert interestingly applies the concept of "escalation dominance" to situations of humanitarian intervention, whereby the primary objective is to stop mass atrocities (also) by coercive means. David C. Gompert, For a Capability to Protect: Mass Killing, the African Union and NATO, 48 SuRviVAL 7, 13 (2006). It bears recalling that escalation dominance usually refers to the military ability of state A to threaten state B with overwhelming retaliation in order to deter B from responding to A's use of force. This definition is adapted from Gareth Porter, Escalation Dominance, RigHT WeB, http://rightweb.irc-online.org/articles/display/Escalation_Dominance (last updated Sept. 27, 2007).

136. See Huth, supra note 131, at 83 n.10.

137. Id.

138. Interestingly, later in the same article Paul K. Huth refers to general deterrence as a theory that applies to "crisis initiation," and to immediate deterrence as addressing "crisis escalation." Id. at 97.

139. Vesna Danilovic, The Sources of Threat Credibility in Extended Deterrence, 45 J. Conflict Resol. 341, 351 (2001); see also Huth, supra note 131, at 83; Huth, supra note 132, at 16 . 
framework suggests that greater attention is necessary in identifying the source of threat. When applying the same framework to the ICC, we should therefore ask whom potential perpetrators actually fear: the ICC or those enforcing its decisions? This adaptation holds the ICC in the same manner as a major power's protégé-which is exactly what happened in Côte d'Ivoire when France took on the role of enforcer. ${ }^{140}$ By unleashing violence domestically, Ivorian leaders challenged ICC proscriptions. $^{141}$ Since the latter had no enforcement power, it was France's task to deter them. While extended deterrence envisages (at least) three players involved in the threat game, it is the interplay between challenger and defender that determines the success or failure of deterrence; the protégé, on the other hand, cannot alter the balance of power in a significant way. Many authors have stressed the need for a framework that incorporates the coercive dimension of deterrence. ${ }^{142}$ Yet, extended deterrence does more than merely reintroducing coercion into the equation. It builds on and speaks to Kenneth Waltz's balance of power, ${ }^{143}$ Stephen Walt's balance of threat, ${ }^{144}$ and Robert Jervis' balance of interest. ${ }^{145}$ It does so by encompassing realist considerations of power,

140. I hereby refer to Opération Licorne (French for Operation Unicorn), a French peacekeeping mission deployed in Côte d'Ivoire in late September 2002. For general information about Opération Licorne, see Operation Unicorn, WIKIPEDIA (Jan. 22, 2015, 11:45 PM), https://en.wikipedia.org/wiki/Operation_Unicorn.

141. On the patterns of violence observed during the first Ivorian civil war, see Daniel Chirot, The Debacle in Côte d'Ivoire, 17 J. Democracy 63, 71-74 (2006); Akhavan, supra note 13, at 636-41. Regarding the second Ivorian civil war, see Straus, supra note 61, at 483-87; Bellamy \& Williams, supra note 61, at 829-38.

142. According to Michael Smidt, for instance, "[t]he military remains the most credible and effective form of deterrence in the international arsenal of weapons to prevent war and massive human rights abuses." Smidt, supra note 3, at 157. Similarly, Kenneth Rodman maintains that "broader deterrent ambitions are dependent upon the capability and willingness of powerful states to back them up." Kenneth A. Rodman, Darfur and the Limits of Legal Deterrence, 30 HuM. RTS. Q. 529, 560 (2008).

143. Kenneth N. Waltz, Theory of International Politics 117-18 (1979).

144. See generally Stephen M. Walt, The Origins of Alliances (Cornell Univ. Press 1987).

145. See generally Robert JeRvis, PERCEPTION AND MisPerception IN International Politics (Princeton Univ. Press 1976); see also Deterrence Theory Revisited, supra note 47, at 314-15; Randall L. Schweller, Bandwagoning for Profit: Bringing the Revisionist State Back In, 19 INT'L SECURITY 72, 99-100 (1994). 
the projection thereof across world regions, state interest on both sides, structural factors such as geographical proximity, and past interactions between challenger and defender.

B. Beyond Rational Deterrence Theory: Signaling the Threat of Sanctions to Potential Atrocities Perpetrators

I mentioned earlier that RDT is mainstream in legal scholarship. ${ }^{146}$ Indeed, it is not an exaggeration to hold that virtually all legal scholars view deterrence through the lens of RDT and, in turn, employ rationalist tenets when designing alternative theories on the same topic. I also stated that several assumptions underlying RDT have been uncritically applied to the ICL regime despite the remarkable differences between domestic and international criminal justice. ${ }^{147}$ One of these assumptions posits that players have perfect information of the pay-off structure-perfect information that amounts to the logical premise for calculating the pros and cons of violating the law, hence deciding whether or not it is worth incurring risks of sanctions. The assumption of perfect information resonates well with another assumption that has always characterized domestic criminal justice systems: ignorance of the law neither affords nor excuses criminal deeds. ${ }^{148}$ Put otherwise, all are presumed to know that criminal law forbids certain conducts, and thus, they are required to behave accordingly. The Rome Statute lists the unlawful actions that qualify as the actus reus of an international crime. In doing so, it surely improved the knowledgeability of ICL proscriptions. Still, the assumption of perfect information is misleading for theorizing international deterrence, as it neither helps to explain variation in outcomes across cases or over time nor does it apply to the source of threat. Empirically, new episodes of mass violence have broken out since July 1, 2002, despite the looming specter of accountability for international crimes. This observation presents a puzzle for those who posit that the mere existence of the ICC can deter atrocities. Clearly, we should look elsewhere for the factor(s) causing deterrence to succeed in

146. See supra note 47 and accompanying text.

147. See supra note 28 and accompanying text.

148. See supra note 50 and accompanying text. 
coercing compliance. By looking at deterrence through the lens of IR theory, we realize that the latter is a function of the specific relationship between challenger and defender (hereby relabeled threatened and enforcer). Conceptually, it follows that the ICC is a trivial condition-a necessary condition retaining very little explanatory power about the observed outcome. Methodologically, the ICC is to be held constant when comparing cases occurred after July 1, 2002 and, as a constant, it cannot be a source of causal inference. All in all, it is fair to conclude that the mere existence of the ICC has had little to no impact on the deterrence of future atrocities.

For political scientists, deterrence is relational; its success hinges on the interaction between players and, in particular, on how the threatened decodes the threat conveyed by the enforcer. Such a framework calls for a theory that does not assume perfect information: signal theory. The threat of sanctions can fail to deter because of how the threatened misperceives the threat. The threatened can interpret the signal in the context of past experiences, inherent biases, personal/historical traumas, etc. ${ }^{149}$ But deterrence can also fail because of the enforcer. For instance, the threat the enforcer sends can appear inconsistent with his stated interests or past actions, resulting in a signal that seems incoherent (or weak) in the eye of the threatened. That said, the question this section purports to answer is how to convey a strong signal - a signal that successfully deters the receiver from committing atrocious crimes. While a complete survey of the literature on deterrence in IR theory is beyond the scope of this article, I draw heavily on this literature for the analytical framework I set forth below. Building on Jervis' work, I distinguish between the pre-bargaining phase, which is defined by state (and statesmen's) interests, and the bargaining phase, which pivots on the central concept of commitment. ${ }^{150} \mathrm{I}$ also divide state interests into intrinsic and strategic, while I disaggregate the broad concept of commitment as to examine the ways and factors that make it credible in

149. See Robert Jervis, Hypotheses on Misperception, 20 World Pol. 454, 46769 (1968); see also JERVIS, supra note 145.

150. Robert Jervis identifies both state interests and commitment in a deductive negative manner by looking at who will lose if it retreats. Deterrence Theory Revisited, supra note 47 , at 314 . 
the eye of the threatened. Notions like coercive capability and reputation belong mostly, albeit not exclusively, to the bargaining phase and, as such, they will be dealt with and placed under the overarching umbrella of commitment.

According to Jervis, state interests are the logical foundation upon which commitment can be built during the bargaining phase. ${ }^{151}$ Within the distinction between intrinsic and strategic interests, he adds that the former lead to the latter. ${ }^{152}$ Put otherwise, "intrinsic interest represents the inherent value that the actor places on the object or issue at stake." 153 In this Article I maintain that France acted as the main enforcer in Côte d'Ivoire, which raises the question of what was France's intrinsic interest in intervening in its former colony. On this point, it is fair to say that Paris had a two-fold interest in taking action. First, French decisionmakers conceived of intervention not only as a means of retaining political and economic influence in the domestic affairs just in Côte d'Ivoire, but also in all former African colonies. ${ }^{154}$ Second, Paris had an interest in presenting itself as the ICC champion, especially in light of the United Kingdom's hesitancy to become militarily involved in Africa during the late stages of the Sierra Leonean civil conflict. ${ }^{155}$ This brief

151. Id. at 315 .

152. Id. at 314 .

153. Id.

154. Foreign policy experts have already stressed that France holds a strong interest in maintaining its special role in Africa:

[France's] engagements with African states have played an important role in sustaining its image as a major power. African countries can be a valuable source of supportive votes at the UN and they have been key allies for France and fellow EU members in international negotiations on certain global issues, notably climate change.

Paul Melly \& Vincent Darracq, A New Way to Engage? French Policy in Africa from Sarkozy to Hollande, Chatham House 3 (2013),

https://www.chathamhouse.org/sites/files/chathamhouse/public/Research/Africa/0513pp franceafrica.pdf. Moreover, according to Maja Bovcon, Côte d'Ivoire's dependence on French military assistance was - and still is - the desired consequence of the former metropole's foreign policy. Maja Bovcon, France's Conflict Resolution Strategy in Côte d'Ivoire and its Ethical Implications, 11 AFR. STUD. Q. 1, 9 (2009).

155. For an account of the British military intervention in Sierra Leone, see Paul Williams, Fighting for Freetown: British Military Intervention in Sierra Leone, 22 CONTEMP. SECURITY POL'y 140 (2001). For an assessment of British military and 
investigation of French intrinsic interest is instrumental in pinpointing French strategic interest in Côte d'Ivoire.

According to Jervis, "[s]trategic interest in a conflict represents the degree to which a retreat would endanger the state's position on other issues, irrespective of its efforts to commit itself to a firm stand." ${ }^{156}$ On this point, it is easy to speculate that, had it not intervened in Côte d'Ivoire, France would have undermined its influence in the African continent and, consequently, its status as a major power in world politics. ${ }^{157}$ From a symbolic standpoint, another compelling reason to intervene stemmed from considerations of what Côte d'Ivoire represented in France's post-colonial foreign policy. Under Felix Houphouët-Boigny's rule, Côte d'Ivoire was internationally recognized for its economic success; global actors openly suggested that other African countries should look at and learn from the Ivorian model so as to achieve solid economic growth and boost industrial capacity. ${ }^{158}$ Côte d'Ivoire, indeed, stood as the epitome of post-colonial Franco-African relations, whereby former colonies consented to-and even welcomedFrench interference in their internal affairs and earned political stability and economic development as a result thereof. ${ }^{159}$ In return for its

financial commitment to Sierra Leone in 2000, see ANDREW M. DORMAN, BLAIR'S Successful War: British Military Intervention in Sierra Leone 66 (Ashgate Publ'g Ltd. 2009).

156. Deterrence Theory Revisited, supra note 47, at 314.

157. On French struggles to maintain the status of major power, see Shaun Gregory, The French Military in Africa: Past and Present, 99 AFr. AfF. 435, 436 (2000); see also Rachel Utley, 'Not to Do Less but to Do Better...'? French Military Policy in Africa, 78 INT'L AFF. 129, 129-30 (2002). On this point, Jean-François Bayart commented that "[r]elations between France and its former possessions[] [looked] surprisingly 'neo-colonial' in the eyes of anglophone observers." JEAN-FrANÇOIS Bayart, The State in Africa: The Politics of the Belly 26 (2d ed. 2009).

158. On Côte d'Ivoire as a model for other African countries, see LAUREN M. MACLEAN, InFormal Institutions AND Citizenship in RURAL AFricA: Risk AND Reciprocity in Ghana and Cote D'Ivoire 3 (Cambridge Univ. Press 2010); Paul Collier, Wars, Guns and Votes: Democracy in Dangerous Places 155 (Harper Collins 2009); Chirot, supra note 141, at 63.

159. Shaun Gregory defines this system of enduring dependence from France as a "virtual empire." Gregory, supra note 157. Christopher Clapham observes that, "in the case of African states, survival was best assured by a state firmly attaching itself to a great power ally or protector." See also Christopher Clapham, Africa AND THE 
patronage, the former metropole successfully reinforced its lasting hierarchical understanding of the international system - an understanding that is reminiscent of David Lake's conceptualization (and measurement) of hierarchy. ${ }^{160}$ In all, it is worth noting that state interest does more than lay the foundations of a credible commitment, as "when interest is great enough, commitment is not necessary." " Because "“[p]olitical patterns are prerequisite to military deterrent success," $" 162$ it is possible to hypothesize that, bearing in mind France's special interests in Côte d'Ivoire and in supporting the ICC, Ivorian leaders would have judged the threat of intervention as credible regardless of a later commitment.

Once intrinsic and strategic interests are identified, the main issue becomes how to signal what they mean to potential perpetrators. In this regard, James Fearon suggests "states attempt to resolve this dilemma ... by making their threats costly signals."163 Logically, the enforcer's ultimate goal is credibility when threatening the use of force without actually having to carry out his threat. According to Fearon, the proper way to add credibility to threats is to incur or create costs the enforcer would not bear if he were unwilling to carry out those threats. ${ }^{164}$ To this end, Fearon sets forth two alternative signaling strategies, namely "tyinghands" and "sunk-cost[s]."165 To tie hands, state leaders "creat[e] audience costs that they will suffer ex post if they do not follow through

International System: The Politics of State Survival 20 (Cambridge Univ. Press 1996); Arnim Langer, Horizontal Inequalities and Violent Group Mobilization in Côte d'Ivoire, 33 Oxford Dev. Stud. 25, 30 (2005).

160. David Lake conceptualizes hierarchy at the international level along two dimensions, namely security and economic hierarchy. David A. Lake, Escape from the State of Nature: Authority and Hierarchy in World Politics, 32 InT'L SECURITY 47, 49 (2007). With regard to Franco-African relations, the establishment of a common currency zone denoted by the CFA Franc speaks to Lake's concept of economic security as an externally-fixed exchange rate regime greatly limits a country's monetary policy autonomy. CLAPHAM, supra note 159, at 93-95.

161. Deterrence Theory Revisited, supra note 47, at 316.

162. Id. at 324 (quoting Bernard Brodie, WAR AND Politics 380 (Macmillan 1973)).

163. James D. Fearon, Signaling Foreign Policy Interests Tying Hands Versus Sinking Costs, 41 J. Conflict Resol. 68, 69 (1997).

164. Id.

165. Id. at 70 . 
on their threat or commitment (i.e., costs arising from the actions of domestic political audiences)." $" 166$ By the opposite token, to sink costs entails "taking actions such as mobilizing troops that are financially costly ex ante." 167 In 2002, Côte d'Ivoire and France chose the latter. With outstanding speed, it launched Opération Licorne and deployed troops on the ground within three days of the failed coup d'état; the initial mission was to protect and evacuate French nationals and other foreigners from the African country. ${ }^{168}$ In addition to the soldiers deployed in the aftermath of the failed coup d'état, France already had 500 troops stationed in Côte d'Ivoire prior to launching Opération Licorne. ${ }^{169}$

But French intervention consisted of more than a display of military might. In fact, it is fair to conclude that it was manifold. France proved willing to spend its political capital to get the UN directly involved in the Ivorian crisis. As a result of French diplomatic action, on February 4, 2003, the UN Security Council unanimously passed resolution 1464, which endorsed the already-signed Linas-Marcoussis peace accord and requested Secretary-General Kofi Annan to formulate recommendations on how the UN could support its implementation. ${ }^{170}$ In other words, this resolution purported to legitimize ex post the two military missions (one by France, the other by the Economic Community of West African States (ECOWAS)) already in place when the above-said resolution was

166. Id. at 68 .

167. Id.

168. See supra note 138 and accompanying text; see also Giulia Piccolino, David against Goliath in Côte d'Tvoire? Laurent Gbagbo's War against Global Governance, 111 AFr. AFF. 1, 2 (2012).

169. Côte d'Ivoire, U.S. DeP'T OF State (Nov. 27, 2009), http://www.state.gov/outofdate/bgn/cotedivoire/144945.htm. On the figures of French troops deployed on the ground in response to the September 19th events, see France Sending More Troops to Ivory Coast as Peace Talks Falter, N.Y. Times (Dec. 13, 2002), http://www.nytimes.com/2002/12/13/world/france-sending-more-troops-to-ivory-coastas-peace-talks-falter.html; see also Gregory, supra note 157, at 438.

170. Press Release, Security Council, Security Council Calls for Full Implementation of Côte d'Ivoire Peace Agreement, Unanimously Adopting Resolution 1464 (2003), U.N. Press Release SC/6997 (Feb. 4, 2003). 
tabled. ${ }^{171}$ On May 13, 2003, the Security Council unanimously adopted resolution 1479, which set up the UN Mission in Côte d'Ivoire-a peacekeeping mission with main objectives that included monitoring the ceasefire and facilitating the implementation of the above-mentioned agreement signed under French auspices (and pressures). ${ }^{172}$ Lastly, France spent further political capital to pressure African allies to participate in the military effort. ${ }^{173}$ As a consequence, in January 2003, the ECOWAS agreed to place around 1500 peacekeepers in Côte d'Ivoire. ${ }^{174}$ Four out of the five countries that eventually decided to join the French military effort were former colonies. ${ }^{175}$ The process of exerting pressure on other states by leveraging asymmetric relations of power, along with the outcome it eventually determined, further strengthened the image of France as primary sender, and thus, as an actor committed to a goal to the point of overcoming collective action problems and acting unilaterally if inter-state cooperation fails. ${ }^{176}$

171. On the a posteriori legitimization of the Linas-Marcoussis accords as well as Opération Licorne, see Bovcon, supra note 154, at 10.

172. The ex post legitimization rationale of UN action is further highlighted by the fact that the Ivorian armed forces, Forces Armées Nationales de Côte d'Ivoire (FANCI), and rebel groups reached a complete ceasefire for the entire territory of Côte d'Ivoire on May 3, 2003, which was ten days before resolution 1479 was adopted. United Nations Mission in Côte d'Ivoire, United NATIONS,

http://www.un.org/en/peacekeeping/missions/past/minuci/chron.html (last visited Jan. 6, 2016); see also Cyril I. Obi, Economic Community of West African States on the Ground: Comparing Peacekeeping in Liberia, Sierra Leone, Guinea Bissau, and Côte D'Ivoire, 2 AFr. SECURITY 119, 129 (2009).

173. Melly \& Darracq, supra note 154 , at 18.

174. Bovcon duly underscores the inconsistency between official pledges and following action. On this point, she recalls,

[initially] the authorized strength of the ECOWAS Mission in Côte d'Ivoire (ECOMICI) was of 2,386 men from Benin, Ghana, the Gambia, Guinea-Bissau, Mali, Niger, Nigeria, Senegal and Togo . . . and was diminished in number since many countries, for various reasons, did not contribute soldiers after all. As a matter of fact, by February 2003, only some 500 ECOWAS troops were deployed on Ivorian soil ....

Bovcon, supra note 154 , at 9.

175. Namely, Senegal, Ghana, Benin, Togo, and Niger.

176. Melly \& Darracq, supra note 154, at 18. 
A full understanding of commitment hinges on - and is intertwined with-military capability. Threatening the use of force is the core of deterrence theory, and the means by which states threaten others (including non-state armed groups for the purpose of this Article) is by employing the military machine. But which military capacity really matters in deterring potential perpetrators? In the case of French intervention in Côte d'Ivoire, for instance, did Gbagbo and his associates take into account the entire French military apparatus or only the soldiers and artillery locally deployed $?^{177}$ To answer these questions, it might be useful to draw on Walt to distinguish between aggregate and offensive power. ${ }^{178}$ The former encompasses both actual and potential military capability; beyond soldiers and weapons, factors such as population, industrial capacity, and technological prowess are to be considered, as they can affect military capacity in the case of war mobilization. ${ }^{179}$ Positing that the Ivorian leadership feared France's aggregate strength is tantamount to state that they considered all of the French soldiers stationed at home and abroad, the entire destructive potential, along with other factors that could become salient in case of an all-out war. Still, sheer balance of power calculations should yield to more sophisticated explanations when there is no geographical proximity between the threatened and the enforcer. Hence the usefulness of employing the concept of offensive power, that Walt defines as "the ability to threaten the sovereignty or territorial integrity of another state at an acceptable cost." ${ }^{180}$ However, rather than state sovereignty or territorial integrity, what was really at stake in Côte d'Ivoire - and dear to leaders' heartswas regime survival. ${ }^{181}$ In their eyes, I contend, the threat posed by

177. On the French military presence in Africa in the period preceding the First Ivorian Civil War, see Gregory, supra note 157, at 438; Utley, supra note 157, at 136-37.

178. WALT, supra note 144 , at 22-25.

179. Id. at 22 .

180. Id. at 24 .

181. On the crucial question of whose survival is at stake (the state's or the ruler's), William Reno notices that "[r]ulers manipulate definitions of sovereignty and statehood to protect their personal authority" and "to serve their own private interests." William RenO, WARLORD POLITICS AND AFricAN STATES 8-9 (Lynne Rienner Publishers 1998). Also, William Burke-White also stresses the importance of disaggregating the 
France amounted to the troops deployed on the ground, the superior air support, and weapon technology. It is also possible to speculate that they took into account troops and weapons readily (re)deployable in Côte d'Ivoire. In fact, France runs three primary military bases on African soil, namely in Senegal, Gabon, and Djibouti, in addition to the soldiers serving in ongoing military operations in Chad and the Central African Republic (CAR). ${ }^{182}$

Lastly, France has a time-honored reputation for resolve in African crises - a reputation that it has eagerly upheld throughout the years despite increasing military and political costs. ${ }^{183}$ But how is reputation defined? And what inference can former African colonies draw from France's long-lasting history of political interference and military intervention in that region? A mainstream definition is put forward by Gregory Miller, for whom "reputation . . . [is] a judgment about an actor's past behavior that is used to predict future behavior." "184 On this point, I contend it is highly unlikely that Ivorian leaders could ignore France's tendency to take action. According to Christopher Griffin, "[b]etween 1960 and early 2008, France launched 43 military operations in Francophone Africa." 185 The list is not exhaustive though, since France recently intervened in Chad, Libya, Mali, and again in the Central Africa

state in order to properly identify the causes underlying the Congolese government's decision to refer its domestic situation to the ICC. Burke-White, supra note 118, at 107.

182. Andrew Hansen, Backgrounder: The French Military in Africa, N.Y. TIMES (Feb. 9, 2007), http://www.nytimes.com/cfr/world/slot2 20070209.html? r=1\&.

183. On France's reputation for resolve in Africa, see, e.g., Marco Wyss, The Gendarme Stays in Africa: France's Military Role in Côte d'Ivoire, 3 AFr. Conflict \& PeAcebuilding ReV. 81, 101 (2013).

184. Gregory D. Miller, Hypotheses on Reputation: Alliance Choices and the Shadow of the Past, 12 SEC. Stud. 40, 42 (2003). Miller's definition is also adopted by Andrew T. Guzman. See Andrew T. Guzman, How International Law Works: A Rational Choice Theory 33 (Oxford Univ. Press ed., 2008).

185. Christopher W. Griffin, French Grand Strategy in Africa in the Fifth Republic (Mar. 28, 2009) (unpublished Ph.D. dissertation, University of Southern California) (on file with the University of Southern California Library system), available at http://digitallibrary.usc.edu/cdm/ref/collection/p15799coll127/id/218417. 
Republic. ${ }^{186}$ Such a well-established reputation for resolve must mean something to the leaders of French-speaking African countries. Scholars have long debated whether region-specific reputations can form, reaching different conclusions on the topic. ${ }^{187}$ While taking a position in this debate is beyond the scope of this article, historical and anecdotal evidence from Côte d'Ivoire, the Democratic Republic of Congo, Guinea, and Mali lend support to the claim that normative and legal concerns can drive French interventions in African crises where atrocity crimes have been - and are being-committed. ${ }^{188}$ From another perspective, this reputation may amount to an enduring reminder to state leaders in Francophone Africa that they can be ousted from power if they unleash widespread and systematic domestic violence. ${ }^{189}$

When is a signal strong? If fear is in the eye of the beholder, how can it be assessed whether or not a threat has been duly received and decoded by its recipient? Drawing on mainstream IR scholarship, I disaggregate the concept of signal into its two attributes, namely state interest and commitment. I further expand the above attributes in order to consider two different categories of interests as well as a number of key factors meant to add credibility to state commitments. In all, the dyad of states under exam represents almost an ideal case. First, France has maintained tight bilateral relations with the Côte d'Ivoire even after the latter

186. On the recent French military intervention in Mali, see Dan E. Stigall, The French Intervention in Mali, Counterterrorism, and the Law of Armed Conflict, 223 MiL. L. REV. 1 (2015).

187. For the affirmative, see Huth, supra note 131, at 92; see also Danilovic, supra note 139 , at 360 . For the negative, see Jonathan MERCER, ReputATION AND InTERnAtional Politics 122 (Cornell Univ. Press 2010). For a neutral observation, see Deterrence Theory Revisited, supra note 47, at 316.

188. On this point, it is worth underscoring the correlation between French military interventions abroad and ICC official investigations (or preliminary examinations). Specifically, France has intervened militarily in the DRC, the CAR, Mali, Côte d'Ivoire, and Libya; incidentally, all of these countries have fallen under ICC scrutiny at different times. Furthermore, the French government actively promoted the UN Security Council referral of Sudan-Darfur to the ICC. BosCO, supra note 10, at 10809 .

189. For an account of France proving unwilling to cooperate with the ICTY and enforce the arrest warrants issued by the latter in the sector of Bosnia patrolled by French troops see HAGAN, supra note 9, at 109-12. 
became independent in $1960 .{ }^{190}$ The former metropole still retains means and ways to exert influence on Ivorian domestic affairs. At the same time, the former colony is well aware of its substantial, albeit informal, dependence from France for political and, most importantly, military assistance. Second, through a consistent foreign policy over time, France has proven that it holds an intrinsic and strategic interest in maintaining its special relationship with former African colonies. Besides state interest, France's reputation for resolve, signaling strategy, and offensive power added credibility to its commitment. In the end, the threatened (i.e., the Ivorian leadership) received a coherent and strong signal: either deescalate violence or face the risk of apprehension and prosecution before the ICC. The risk of misperceptions was minimal.

C. From Practice to Theory: An Inductive Approach for Theorizing International Deterrence

Thus far, I have discussed the threat of ICC prosecution without actually putting forward a working definition thereof. As a subset of international prosecution, ICC prosecution amounts to the institutional and normative response to the perpetration of organized and widespread episodes of violence. As Table 1 shows, ICC prosecution is jointly determined by two main casual factors: the gravity of violence and elite involvement in the perpetration thereof. ${ }^{191}$

\begin{tabular}{|c|c|c|}
\hline ICC Prosecution & $\begin{array}{c}\text { Elite Involvement - } \\
\text { Low }\end{array}$ & $\begin{array}{c}\text { Elite Involvement - } \\
\text { High }\end{array}$ \\
\hline
\end{tabular}

190. See Gregory, supra note 157 , at 435 ; Wyss, supra note 183 , at $85-86$.

191. David Bosco recalls that, during Moreno-Ocampo's tenure in office, the key metric for ranking the gravest situations over which the court had jurisdiction was violent deaths in the last several years. BOSCO, supra note 10, at 90 . On elite involvement, see generally supra note 62 and accompanying text. For yet another example of how elite involvement is a necessary condition for atrocity crimes, see JOHN HAGAN \& WENONA Rymond-Richmond, DARFur AND the CRIme of Genocide 3, 6-7, 16-17, 27-28 (Cambridge Univ. Press 2009). 


\begin{tabular}{|c|c|c|}
\hline $\begin{array}{c}\text { Gravity of } \\
\text { Violence - High }\end{array}$ & $\begin{array}{c}\text { Disorganized } \\
\text { Widespread Violence } \\
\text { (e.g., riots) }\end{array}$ & $\begin{array}{c}\text { Organized Widespread } \\
\text { Violence (e.g., civil } \\
\text { conflict, genocide) }\end{array}$ \\
\hline $\begin{array}{c}\text { Gravity of } \\
\text { Violence - Low }\end{array}$ & $\begin{array}{c}\text { Disorganized Limited } \\
\text { Violence (e.g., } \\
\text { domestic crime) }\end{array}$ & $\begin{array}{c}\text { Organized Limited } \\
\text { Violence (e.g., } \\
\text { repressive regimes) }\end{array}$ \\
\hline
\end{tabular}

Table 1 - ICC Prosecution as a function of the Nature of Violence: Ideal Typology

Visually, ICC prosecution occurs only in the upper-right quadrant, where there is both high gravity of violence and elite involvement. What this two-by-two matrix is unable to capture, however, is how much (and what kind of) violence is enough to place any given episode in the upper, rather than the lower, row. The risk is to realize that the gravity threshold is met when it is already too late. To date, there is virtually no guidance on how to ex ante set the bar of the gravity threshold, and such a lack of guidance is loaded with theoretical implications for the ICC's deterrent impact. Indeed, this is where normative and utilitarian considerations on what the ICC is meant to accomplish diverge to the point that they become mutually exclusive.

To maximize the ICC's deterrent potential, I argue that guidance by the OTP or other ICC offices is urgently needed. The logic is fairly intuitive: guidance on where to set the gravity threshold would enable the OTP to develop strategies aimed at preventing the escalation of mass violence. Conversely, the current lack of guidance makes it virtually impossible for the OTP to build on immediate deterrence and thus convey incremental signals - signals whereby the likelihood of ICC prosecution increases with the level of violence perpetrated until the gravity threshold is finally met. But to establish at what point the gravity threshold applies implies utilizing non-legal considerations. The ICC works on a limited budget and simply cannot investigate all of the episodes of violence that break out globally. As a consequence, only certain situations fall under OTP scrutiny, ${ }^{192}$ and gravity of violence

192. Punyasena, supra note 103 , at $41,47$. 
remains the main driver in OTP current case selection practice. ${ }^{193}$ Since a certain amount of violence is de facto tolerated, the underlying idea is to instrumentally use it to enhance the ICC's deterrent potential. According to ICC officials, however, setting a quantitative threshold is not in the Court's interest. ${ }^{194}$ In this view, the ICC is a judicial organ that neither is nor should be concerned with non-legal considerations. ${ }^{195}$ It follows that its only recommendation for avoiding ICC prosecution is to abstain from committing or being involved in the commission of atrocities in the first place. That said, normative considerations rule out the possibility of taking advantage of the ICC's practical limits for the purpose of enhancing its deterrent impact in ongoing conflicts or episodes of mass violence.

Pinpointing which causal factors determine ICC prosecution is also helpful to understand which factors do not. I already mentioned that the mere threat of ICC prosecution voiced by random actors has seldom, if ever, proved successful without the backing of major powers willing to bear enforcement costs. ${ }^{196}$ From the study of the Côte d'Ivoire case I extracted two independent variables that, combined in a specific manner, made the threat of ICC prosecution successful in deterring mass atrocities. The two variables are the likelihood of arrest or prosecution before the ICC and leadership survival. ${ }^{197}$ The former is mostly

193. SáCouto \& Cleary, supra note 103, at 808; BOSCO, supra note 10, at 90.

194. That opinion was unanimously held by the ten officials interviewed, who are employed by different offices, including the OTP, Trial chambers, and the Registrar. Interview with employees in the ICC's Office of the Prosecutor in the Hague (July 7, 2014) (details withheld for anonymity purposes). According to another ICC officer, it is better to leave the gravity threshold vague as it is, so that potential perpetrators cannot build expectations on how much violence can go unpunished. Interview with an ICC officer in the Hague (July 15, 2014) (details withheld for anonymity purposes). This reasoning, however, assumes that potential perpetrators, (1) fear the threat of sanctions; and (2) are risk-averse.

195. Id.

196. See supra pp. 391-92.

197. In his seminal Africa and the International System, Christopher Clapham asks whose survival is at stake: the state's, or the ruler's? He argues that "[i]n the great majority of cases rulers seek to assure their personal survival by seeking the survival and indeed strengthening of their states. They can on the whole best protect their own security by preserving and enhancing the power of the states which they rule." CLAPHAM, supra 
concerned with the credibility of threat, which is a function of whoever acts as enforcer. The latter focuses on the threatened, in particular on whether domestic decision-makers hold a positive (or negative) outlook regarding their chances to retain power in the short-term at the time the threat of ICC prosecution occurs. ${ }^{198}$ A preliminary comment on Table 2 is timely. In the latter I dichotomize both independent variables for explanatory purposes, whereas they are better conceived as continuum.

\begin{tabular}{|c|c|c|}
\hline $\begin{array}{c}\text { International (ICC) } \\
\text { Deterrence }\end{array}$ & $\begin{array}{c}\text { Arrest or } \\
\text { Punishment- } \\
\text { High Likelihood }\end{array}$ & $\begin{array}{c}\text { Arrest or } \\
\text { Punishment- } \\
\text { Low Likelihood }\end{array}$ \\
\hline $\begin{array}{c}\text { Leadership } \\
\text { Survival- } \\
\text { Positive Outlook }\end{array}$ & $\begin{array}{c}\text { Threat of ICC } \\
\text { Prosecution Works }\end{array}$ & $\begin{array}{c}\text { Institutional } \\
\text { Reaction: } \\
\text { Gamesmanship }\end{array}$ \\
\hline $\begin{array}{c}\text { Leadership } \\
\text { Survival- } \\
\text { Negative Outlook }\end{array}$ & $\begin{array}{c}\text { Target's “All-In" } \\
\text { Strategy: } \\
\text { Peace vs. Justice }\end{array}$ & $\begin{array}{c}\text { Threat Deflection: } \\
\text { Brinkmanship }\end{array}$ \\
\hline
\end{tabular}

Table 2 - International Deterrence: Ideal State Strategy Typology

The first independent variable that jointly determines successful deterrence is leadership survival. I further disaggregate this notion so as to account for two intertwined dimensions thereof: physical and political survival. Physical survival applies to state and rebel leaders alike. Individuals acting under the imminent threat of death or capture have no tangible incentive to comply with ICC norms. ${ }^{199}$ This assertion resonates

note 159, at 4-5. In brief, Clapham's notion of personal survival can be considered close to a synonym of what I label "leadership survival," as both include the personal as well as the political dimension of ruler's survival.

198. According to Brian L. Job, "[s]tates (more appropriately, regimes) are preoccupied with the short term; their security and their physical survival are dependent on the strategies they pursue for the moment." Job, supra note 26, at 27.

199. On the fate of Africa's ex-leaders, Arthur Goldsmith finds that, between 1960 and 1999, sixty-four percent of African rulers have been overthrown; within the latter 
well with teachings drawn from behavioral economics ${ }^{200}$ and leader survival scholarships. ${ }^{201}$ Regarding political survival, the case of Côte d'Ivoire suggests that state leaders see it as a function of internal and external legitimacy. ${ }^{202}$ At first glance, the same case study also supports the claim that internal and external legitimacy are each sufficient for state leaders to retain a positive outlook on their political survival. Yet, a

subset, slightly more than twenty-five percent faced violent death. Arthur A. Goldsmith, Risk, Rule and Reason: Leadership in Africa, 21 Pub. Admin. \& Dev. 77, 82 (2001).

200. Drawing on the teaching of behavioral economics, we learn that individuals usually fail to behave like narrowly self-interested subjects. Philip Roessler further insists on the incumbents' gloomy perceptions of survival. He explains that rulers, fully cognizant of the possibility of being violently overthrown, "experience[] a profound psychological reaction to the nearly loss of power. . . Emotionally shaken and paranoid about the possibility of subsequent threats to their survival, rulers desperately seek to reinforce their grip on power and purge their regimes of all disloyalists." Philip Roessler, The Enemy Within: Personal Rule, Coups, and Civil War in Africa, 63 World Pol. 300, 312-13 (2011).

201. On authoritarian leaders' risk-prone military attitude and struggle to extend their tenure in power, see supra note 166. On state strategies to co-opt political rivals in the executive, see Leonardo R. Arriola, Patronage and Political Stability in Africa, 42 COMP. Pol. STUD. 1339, 1339 (2009). On the rationality of committing atrocity crimes, Kathryn Sikkink notices that "repression often allows officials to confront and punish their political opponents, prolonging in the process their own regimes and careers." SIKKINK, supra note 44, at 171.

202. I draw on Fred Riggs' definition of (internal) legitimacy. In his words, "[t]he legitimacy of a regime depends, in general, on widespread acceptance of a myth that promises valued benefits in exchange for recognition of authority and obedience to those in power." Fred W. Riggs, Ethnonationalism, Industrialism, and the Modern State, 15 THIRD WORLD Q. 583, 589 (1994). On external legitimacy, I borrow from Robert Jackson's notion of "quasi-states" in the international society. According to Jackson, Southern "states actually derive much of their legitimacy from the norms of international society which recognise the state as the ultimate and final authority in terms of internal political policies." John Glenn, The Interregnum: The South's Insecurity Dilemma, 31 NATiOns \& NATiONALisM 45, 59 (1997). On the opportunity to distinguish between external and internal legitimacy, see Robert H. Jackson \& Carl G. Rosberg, Why Africa's Weak States Persist: The Empirical and the Juridical in Statehood, 35 WorLd POL. 1, 7 n.15 (1982). Additionally, Hyeran Jo and Beth Simmons draw a similar relationship between concerns on legitimacy and deterrence. See generally Hyeran Jo \& Beth A. Simmons, Can the International Criminal Court Deter Atrocity? (Dec. 14, 2014) (unpublished manuscript), available at http://papers.ssrn.com/sol3/papers.cfm?abstract_id=2552820. 
more prudent conclusion suggests that the two are necessarily intertwined. The sheer loss of international legitimacy that followed Gbagbo's refusal to step down, despite having lost the 2010 presidential elections, eventually undermined its domestic equivalent. ${ }^{203}$

As said, when state or rebel leaders perceive their survival to be at stake, non-compliance with the law becomes the second-worst option. Relatedly, the cost/benefit analysis on which RDT pivots loses its leverage in inducing compliance. If these premises are correct, we should observe increased likelihood of choosing repression as state (or rebel) leaders perceive defeat as imminent. This raises a policy conundrum, for RDT fails to apply in situations when domestic power-wielders are more likely to unleash violence. ${ }^{204}$ Also, to date it is unknown whether the OTP has devised an alternative strategy to cope with those situations. To be clear, there is no theory claiming that the threat of criminal sanctions can deter all actors at all times, yet legal scholars seem to focus too much on actors' character (disposition) and too little on behavior induced by circumstance (situation). ${ }^{205}$ Because circumstances do matter, I stress the importance of (re)considering the role of amnesties, as they can provide a substitutive pay-off structure. Such a structure would apply when the violence perpetrated has already met the gravity threshold and certain individuals have become worthy of ICC prosecution. It is at this stage

203. In explaining why the universalistic process of fair and competitive elections survives despite pervasive clientelism and blurred boundaries between the public and private spheres, Guillermo O'Donnell maintains,

Part of the answer, at least with respect to elections to top national
positions, is close international attention and wide reporting abroad of
electoral irregularities. Fair elections are the main, if not the only,
characteristic that certifies countries as democratic before other
governments and international opinion. Nowadays this certification has
important advantages for countries and for those who govern them.

Guillermo A. O'Donnell, Illusions about Consolidation, 7 J. Democracy 34, 45 (1996).

204. That considerations about the future are necessary for deterrence to work properly seems to be a truism even among political scientists. For example, Jeremy Weinstein holds that "[m]echanisms of deterrence depend on the fact that individuals care about the future." Jeremy M. Weinstein, Inside Rebellion: The Politics of Insurgent VIOLENCE 350 (Cambridge Univ. Press 2006).

205. Here I apply Gregory Miller's framework on reputation formation to predict criminal behavior. Miller, supra note 184 , at $42-43$. 
that, if conflict is still ongoing, amnesties could deescalate violence by providing perpetrators with a positive incentive to do so. That said, both ICTs' jurisprudence and mainstream legal scholarship overlook the importance of using amnesties selectively. ${ }^{206}$ For instance, in several occasions The Special Court for Sierra Leone judges upheld that domestic amnesties do not cover international crimes. ${ }^{207}$ By the same token, the ICC can "tak[e] the power to give effective amnesties away from [national] government[s]." ${ }^{208}$ The message ICC professionals and advocates are trying to convey is that compliance with international law is not negotiable. Such a stance adds further credibility to the threat of ICC prosecution, but it does so at the cost of excluding any room for political compromises on the issue of amnesties and other forms of judicial pardon. However, if the empirical distinction between the commission and escalation of violence is more than cheap-talk for international lawyers, the role of amnesties must be reconsidered.

On leadership survival, it is worth noting that the case of Côte d'Ivoire concerns exclusively state actors. Regarding non-state actors, and rebel leaders in particular, I contend that the same framework applies, although the internal dynamics of rebel groups sometimes bring about puzzling outcomes. ${ }^{209}$ Yet, for the majority of cases pending before the ICC, rebel actors behaved as predicted in Table 2. ${ }^{210}$ Cross-case

206. See supra pp. 362-63, note 27 and accompanying text. Notable exceptions include Snyder \& Vinjamuri, supra note 83, at 6; The Amnesty Exception, supra note 3, at 508-09; Eric D. Blumenson, The Challenge of a Global Standard of Justice: Peace, Pluralism, and Punishment at the International Criminal Court, 44 Colum. J. TRANSNAT'L L. 797, 799 (2006).

207. Charles C. Jalloh, Contribution of the Special Court for Sierra Leone to the Development of International Law, 15 AFR. J. INT'L \& COMP. L. 165, 185-87 (2007).

208. Ginsburg, supra note 1, at 507.

209. At the same time it is worth pointing out that certain cases deserve further study as they potentially challenge my theory. One prominent example is Bosco Ntaganda's surrender to the US Embassy in Kigali and his formal request to be transferred to the ICC. Rumors were that his decision reflected his conviction that turning himself over to the Court was his only chance to stay alive. DR Congo: Bosco Ntaganda appears before ICC, BBC NEWS (Mar. 26, 2013), http://www.bbc.co.uk/news/worldafrica-21933569.

210. The Lord's Resistance Army is perhaps the clearest example of a non-state armed group acting in utter disregard of international laws. A similar point can be made 
analysis suggests that, upon receiving an arrest warrant or being formally investigated by the Court, both state and rebel actors tend to continue in their misconducts. ${ }^{211}$ From another viewpoint, arrest warrants and formal investigations do not seem to play a significant role in preventing either the commission or escalation of violence. Perhaps the only noteworthy difference is that these legal institutes undermine rebel actors' legitimacy more rapidly than state actors' legitimacy. The Bosco Ntaganda case leads us to believe that ICC scrutiny can stigmatize a rebel leader, turning him into a liability for his own group and providing other group members with an incentive to remove him from command. ${ }^{212}$ That said, as this article is limited in scope and length, future research is needed to understand how the threat of ICC prosecution affects non-state actors.

The second independent variable, namely the risk of being arrested and/or prosecuted before the ICC, is closely related to threat credibility. The issue of how to credibly signal state commitment has been dealt with at length in the previous subsection. As said, the more credible the enforcer, the more likely the threatened will end up facing justice in The Hague. The logic at play between the two (main) parties is reminiscent of card games, in particular poker. Like in poker, the threatened must adjust his strategy depending on who is the opponent. Analytically, it is crucial to remember the distinction between threatener and enforcer. For instance, in the following section I examine a specific case wherein the threat of ICC prosecution successfully prevented the escalation of

with regard to several armed groups active in eastern Congo (e.g., the Congolese Rally for Democracy-Goma) supported by the Rwandan government, Mai-Mai groups of local combatants), in Sudan-Darfur (United Resistance Front), or northern Mali (Ansari Dine). For an episode of (reported) successful deterrence, see Song, supra note 7, at 207.

211. In Côte d'Ivoire, the de facto partition created by the Linas-Marcoussis accords did not stop hostilities between (and the commission of atrocities by) the FANCI and the Forces Nouvelles de Côte d'Ivoire led by Guillaume Soro. Most of the fighting ended by late 2004, yet the conclusion of the first Ivorian civil war was officially sanctioned with the signing of the Agreement of Ouagadougou on March 4, 2007. On the atrocities committed in the aftermath of the 2010 presidential elections by both proGbagbo and pro-Ouattara forces see Straus, supra note 61, at 486-87.

212. Laura Heaton, Bosco Ntaganda, 'The Terminator,' Surrenders to the U.S., DAily BEAST (Mar. 21, 2013), http://www.thedailybeast.com/articles/2013/03/21/boscontaganda-the-terminator-surrenders-to-the-u-s.html. 
violence (see Table 3, CIV(1)). ${ }^{213}$ Here, the UN adviser on the prevention of genocide, Mr. Juan Méndez, voiced the threat of ICC prosecution, ${ }^{214}$ while the French army acted as enforcer. In my framework, Mr. Méndez played no role. The salient interaction is the one linking the Ivorian government (threatened) to the French army (enforcer). In another instance (see Table 3, CIV(3)), ${ }^{215}$ regional political actors warned Gbagbo to desist from his war efforts, while the subject tasked with enforcing the threat of ousting him from power was the ECOWAS. ${ }^{216}$ Accordingly, Gbagbo crafted his response based on the enforcer's interest, commitment, and military capability. ${ }^{217}$

Finally, I discuss the alternative outcomes determined by moving along the two IVs of Table 2. The two outcomes placed in the right column, namely gamesmanship and brinkmanship, share a similar logic. In both, the absence of a credible enforcer undermines the perpetrators' perception of actually facing criminal sanctions. Whether the gravity threshold has already been met is just one consideration domestic decision-makers hold in mind when gauging their chances of maintaining power in the short-run. When the outlook on leadership survival is positive, decision-makers have an incentive to formally play by (or at least not openly defy) the rules of the international system. By doing so, they further raise the cost of intervention for already recalcitrant enforcers. One case that aptly shows the logic of gamesmanship is Kenya in years following the electoral violence of late 2007/early 2008. Already a state party to the Rome Statute, Kenyan authorities contested, but were unable to prevent, the first motu proprio investigation by the OTP. ${ }^{218}$

213. See infra Table 3.

214. Akhavan, supra note 13, at 639-40.

215. See infra Table 3.

216. On the ECOWAS's intervention in Côte d'Ivoire and its legality, see generally Julie Dubé Gagnon, ECOWAS's Right to Intervene in Côte D'Ivoire to Install Alassane Ouattara as President-Elect, 3 Notre Dame J. InT'L \& COMP. L. 51 (2013).

217. On Laurent Gbagbo's brinkmanship, see McGovern, supra note 20, at 79; Bellamy \& Williams, supra note 61 , at 834.

218. On the political bargaining preceding Moreno-Ocampo's decision to launch the Kenya investigation, see Andreas Th. Müller \& Ignaz Stegmiller, Self-Referrals on Trial From Panacea to Patient, 8 J. INT'L CRIM. Just. 1267, 1294 n.115 (2010); Ignaz 
Then, state leaders formally pledged cooperation with the Court while substantially buying time and undermining its action. ${ }^{219}$ So far, it is possible to pinpoint three tactics considered and/or employed by Kenyan leaders. The first tactic was to implement domestic means of justice in order to reclaim the primacy of state jurisdiction over the ICC. Second, domestic power-wielders sought to further delay ICC investigations by taking advantage of article 16 of the Rome Statute. ${ }^{220}$ Supported by the African Union, Kenyan authorities "requested that the U.N. Security Council defer the cases against Uhuru Kenyatta and his number two, William Ruto, for one year to allow them to deal with the aftermath of an attack by al Qaeda-linked Somali militants." 221 Third, they actively undermined ICC operations on the ground. For investigations to succeed, full access to places, witnesses, and documents was required yet systematically denied or hampered. ${ }^{222}$ The quite unfortunate outcome, at least from an ICC standpoint, is that the OPT had withdrawn the charges of crimes against humanity against Kenya's President Uhuru Kenyatta due to lack of evidence. ${ }^{223}$ In all, a procedural ruling made up a political victory in this state struggle against the ICC. ${ }^{224}$

Stegmiller, The International Criminal Court and Mali: Towards More Transparency in International Criminal Law Investigations?, 24 CRIM. L. F. 475, 478 n.13 (2013).

219. Id.

220. The Rome Statute maintains,

No investigation or prosecution may be commenced or proceeded with under this Statute for a period of 12 months after the Security Council, in a resolution adopted under Chapter VII of the Charter of the United Nations, has requested the Court to that effect; that request may be renewed by the Council under the same conditions.

Rome Statute, supra note 4.

221. Michelle Nichols, Africa Fails to get Kenya ICC Trials Deferred at United Nations, REUTERS (Nov. 15, 2013), http://www.reuters.com/article/2013/11/15/us-kenyaicc-un-idUSBRE9AE0S420131115.

222. See Bosco, supra note 10 , at 158 .

223. ICC Drops Uhuru Kenyatta Charges for Kenya Ethnic Violence, BBC NEws (Dec. 5, 2015), http://www.bbc.com/news/world-africa-30347019.

224. For more detailed accounts on the Kenya situation at the ICC, see YvonNE Dutton, Rules, Politics, and the International Criminal Court: Committing to THE COURT 137-55 (Routledge 2013); Susanne D. Mueller, Kenya and the International Criminal Court (ICC): Politics, the Election and the Law, 8 J. E. Afr. STUD. 24, 25-26, 
The outcomes placed on the bottom row of Table 2 share a negative outlook on leadership survival. As state leaders perceive an increasing risk of losing power, the difference between what I label "all-in" strategy and brinkmanship lies in whether or not they face an external threat serious enough to affect internal decision-making on the use of violence. For brinkmanship, threats of ICC prosecution, voiced by random political actors, are not accompanied by committed enforcers. When this is the case, the threatened stands firm and calls the threatener's bluff. ${ }^{225}$ Hence, there is no expectation to observe change in the behavior of the threatened. Finally, the so-called "all-in" strategy requires the presence of a credible enforcer and a negative outlook on leadership survival. Here, the threat of ICC prosecution is not only unlikely to deescalate violence, but it can also exacerbate it. The lower-left quadrant represents those cases wherein RDT has failed to deter and state leaders no longer have an incentive to restrain their actions for the fear of criminal sanctions. ${ }^{226}$ I claim that it is precisely in these cases that the offer of amnesty could possibly deescalate and even stop violence. Conversely, formulating the same offer when state leaders retain a positive outlook on their future may amount to a get-out-of-jail-free card, whereas in cases of brinkmanship the risk of arrest or prosecution is such that there is no need envisage forms of judicial pardon.

\section{Outside the Political Vacuum: The Need for Understanding African Politics}

Despite its global mission, as a matter of fact the ICC has thus far dedicated most attention and resources to Africa. By raising this point, however, I neither aim to join the rank of ICC critics nor do I support its alleged bias against African leaders. Rather, I contend that a greater understanding of the local political landscape can only enhance the

29-30 (2014); Gabrielle Lynch, Electing the 'Alliance of the Accused': The Success of the Jubilee Alliance in Kenya's Rift Valley, 8 J. E. AFR. STUd. 93, 104 (2014).

225. Bellamy \& Williams, supra note 61 , at 834.

226. Libya in the last few months of Qaddafi's life and tenure in power aptly illustrates a situation wherein state leaders on the brink of military defeat and political demise have no incentive to restrain violence against enemies or civilians. 
explanatory power of future mid-level theories on deterrence. That said, it might be the right time to question whether certain assumptions regarding international justice apply to African and non-African settings alike. ${ }^{227}$ While all are equal before the law, not all play by the same rules when it comes to politics. If so, what does it entail to be the incumbent leader(s) of an African country? In Claude Ake's words, in most of Africa, "politics remained a zero-sum game; power was sought by all means and maintained by all means. Colonial rule left . . . Africa a legacy of intense and lawless political competition amidst an ideological void and a rising tide of disenchantment with the expectation of a better life. ${ }^{228}$ Once in power, moreover, the new incumbent normally seizes state resources, excluding rival groups from access to public goods and services.

Under these circumstances, electoral turnover is not meant to redress this unfair distribution of state resources between government and opposition, but rather to provide the latter with an opportunity to start discriminating in turn. ${ }^{229}$ As a consequence, the incumbent likely adopts ex ante measures aimed at influencing (and even predetermining) electoral outcomes. In Côte d'Ivoire, for instance, Laurent Gbagbo inherited from his predecessors a set of institutions and rules whereby "elections are so marred by repression, candidate restrictions, and/or fraud that there is no uncertainty about their outcome." ${ }^{230}$ If they nevertheless happen to lose in the polls, sitting leaders are fully cognizant that they are highly unlikely to ever compete in free and fair

227. See HAGAN \& RyMOND-Richmond, supra note 191, at 67, 69, 76.

228. Claude AKe, Democracy and Development in Africa 7 (Brookings Inst. Press 1996); see also CLAPHAM, supra note 159, at 57.

229. According to Christopher Clapham, "[t]he multiparty electoral systems which in most African states were introduced by the departing colonial regime in the last few years before independence could not be expected to provide a viable framework for the allocation of political power once independence had been achieved." CLAPHAM, supra note 159 , at 53 .

230. Steven LeVitski \& LuCAn Way, Competitive Authoritarianism: Hybrid Regimes After the Cold War 7 (Cambridge Univ. Press 2010). They label cases like Côte d'Ivoire as "hegemonic regimes." These regimes are even less open to electoral turnover than "competitive authoritarian" ones, which are the bulk - and main topic — of the book. See ClaPHAM, supra note 159, at 56. 
elections again. In consequence, elections become a catalyst for infrastate violence, which explains why the OTP has begun to issue preventive public statements in hopes of raising the cost for local entrepreneurs to actually engage in post-electoral atrocities.

Relatedly, even when opposition groups are allowed to organize into political parties, they have few incentives to compete in electoral competitions biased in favor of the incumbent, yet they usually do participate. $^{231}$ This is because political competition between the incumbent and opposition unfold in ways that are quite different from dynamics we observe in Western democracies. Incumbents can behave as set forth by Leonardo Arriola, for whom "African leaders extend their tenure in office by expanding their patronage coalition through cabinet appointment[]." ${ }^{232}$ Opposition groups are therefore co-opted by the incumbent and offered access to state resources in return for loyalty; or they can abandon institutional settings and turn into a rebel group. Opposition and rebel groups both pursue (or are assumed to pursue) a political objective, ${ }^{233}$ but in a civil war scenario the latter, not the former, become the incumbent's counterpart. The international community's preference for inclusionary power-sharing deals further neglects the role of political parties, whereas it legitimizes rebel groups by inviting them to the negotiations table. ${ }^{234}$ On the structural factors directly affecting the

231. On this point, Clapham duly reminds that "[i]n no state on the African mainland, from independence through to 1990, did any opposition party gain power as the result of winning a general election against an incumbent government." CLAPHAM, supra note 159 , at 56 .

232. Arriola, supra note 201; see also Nicolas van de Walle, Meet the New Boss, Same as the Old Boss? The Evolution of Political Clientelism in Africa, in PATRONS, Clients and Policies: Patterns of Democratic Accountability and Political Competition 50-67 (Herbert Kitchent \& Steven I. Wilkinson eds., Cambridge Univ. Press 2007). On group cooptation into the governing structure, see ClAPHAM, supra note 159 , at 59,71 .

233. On the role of ideology (or lack thereof) for armed groups involved in "new wars," see generally KALDOR, supra note 68.

234. On power-sharing agreements sponsored by international actors and the effects these have on internal institutional dynamics, see Denis M. Tull \& Andreas Mehler, The Hidden Costs of Power-Sharing: Reproducing Insurgent Violence in Africa, 104 Afr. AfF. 375, 376, 386 (2005); Andreas Mehler, Peace and Power sharing in Africa: A Not So Obvious Relationship, 108 AFR. AFF. 453, 465-68 (2009); Andreas 
onset of new civil wars, Lars-Erik Cederman, Kristian Skrede Gleditsch, and Simon Hug find that the size of marginalized ethnic groups is a significant indicator of whether or not and for which purpose violence will be used; large groups aim to seize power from the incumbent (governmental conflict), while small ones pursue secession or greater autonomy from central authorities (territorial conflict). ${ }^{235}$ They also find that "after competitive elections smaller ethnic groups are more likely to engage in territorial conflicts, whereas after both competitive and noncompetitive elections, larger groups are more likely to start a conflict seeking to replace the central government." ${ }^{\text {236 }}$ Recalling that the rebel groups that launched a coup d'état in fall 2002 supported candidates who were not allowed to run in the 2000 presidential elections, ${ }^{237}$ it would thus be correct to categorize the first Ivorian civil war as a governmental conflict.

Still, ICL practitioners may not yet realize how much violence occurs on the ground. On this point, McGowan examines the striking pattern of successful and failed coups d'états, along with coup plots, over a period of time running from 1956 to $2001 .^{238} \mathrm{He}$ finds that the region more at

Mehler, Rebels and Parties: The Impact of Armed Insurgency on Representation in the Central African Republic, 49 J. Modern Afr. STUd. 115, 135 (2011). Mary Kaldor duly points out that a key drawback of negotiating solutions between the warring parties is that "the talks usually involve those who are responsible for violence. Thus they raise the profile of the warring parties and confer a sort of public legitimacy on individuals who may be criminals." KALDOR, supra note 68 , at 126 . On the political legitimization of insurgents through externally-sponsored negotiations, see CLAPHAM, supra note 159, at 225; Stefaan Smis \& Wamu Oyatambwe, Complex Political Emergencies, the International Community \& the Congo Conflict, 29 Rev. AfR. Pol. ECON. 411, 419 (2002); Michael Niemann, War Making and State Making in Central Africa, 52 AFR. TODAY 21, 31 (2007).

235. Lars-Erik Cederman et al., Elections and Ethnic Civil War, 46 CoMP. PoL. STUD. 387, 394 (2013).

236. Id. at 389 .

237. Namely Alassane Ouattara and Henri Konan Bédié.

238. Patrick J. McGowan, African Military Coups D'état, 1956-2001: Frequency, Trends and Distribution, 41 J. MOD. AFR. STUD. 339 (2003); see also Goldsmith, supra note 199. Additionally, Christopher Clapham noticed that "the overthrow of nationalist governments by military coups d'état . . . became a fairly regular occurrence from the mid-1960s onwards." Clapham, supra note 159, at 50-51. Updated data on coups occurred globally can be found in Jonathan M. Powell \& Clayton L. Thyne, Global 
risk of political instability is, unsurprisingly, Western Africa. ${ }^{239}$ One of the countries that experienced all three of these violent forms of antiregime activity is Côte d'Ivoire, starting with a coup plot in 1991, followed by a successful coups d'état in 1999, and a failed one in $2000 .^{240}$ In updating McGowan's data set, it is worth noting that rebel forces launched another coups d'état in 2002. Gbagbo's five-month-long attempt to hold on to power after having lost the 2010 presidential elections can also be regarded as a coups d'état. ${ }^{241}$ This brief historical digression lends support to the incumbents' obsession for security and regime stability. Beyond Côte d'Ivoire, recent history provides several other instances in which incumbents blatantly violated ICL proscriptions in hopes of maximizing their likelihood of survival. The list includes the ruling military junta in Guinea (2009), ${ }^{242}$ Muammar Gaddafi in Libya (2011), ${ }^{243}$ and Bashar al-Assad in Syria (2013). ${ }^{244}$

Another noteworthy peculiarity about African politics is that leaders' physical and political survivals often conflate. ${ }^{245}$ Abel Escribà-Folch and Joseph Wright call these power arrangements "personalist

Instances of Coups from 1950 to 2010: A New Dataset, 48 J. PeACE ReS. 249 (2011). On Africa specifically, Powell and Thyne observed 169 coup attempts between 1950 and 2010 , with a success rate of $51.5 \%$. Id . at 255 .

239. McGowan, supra note 240, at 355-56.

240. Id. at 365-66.

241. The idea is that, since Gbagbo had lost the 2010 presidential elections to Ouattara, his de facto control of the state was nevertheless illegal; as such, his tenure in power during the months following his electoral defeat could be regarded as an unconstitutional change in power. On this point, see Gagnon, supra note 216, at 65-66; see also Sean Butler, Separating Protection from Politics: The UN Security Council, the 2011 Ivorian Political Crisis and the Legality of Regime Change, 20 J. Conflict \& SECURITY L. 251, 255 (2015).

242. On the atrocities allegedly committed by the Guinean military junta, see Rob Grace, From Design to Implementation: The Interpretation of Fact-finding Mandates, 20 J. CONFLict \& SECURity L. 27, 46, 56 nn.136, 37 (2015).

243. Bellamy \& Williams, supra note 61, at 838-46; Siba N. Grovogui, Intricate Entanglement: The ICC and the Pursuit of Peace, Reconciliation and Justice in Libya, Guinea, and Mali, 40 Afr. DEV. 99, 106-10 (2015).

244. See Kirsten Ainley, The Responsibility to Protect and the International Criminal Court: Counteracting the Crisis, 91 InT'L AfF. 37, 38-42 (2015).

245. On this conflation, see ClAPHAM, supra note 159, at 4-5. 
dictatorships." 246 According to them, "[p]ersonalist dictatorships stand apart from regimes based on an institutionalized organization such as a party or the military. Leaders in these autocracies often rely on relatively small support coalitions whose loyalty is ensured by the distribution of material rewards." 247 Similarly, Michael Bratton talks about "Big Man" presidentialism when referring to the same power arrangement. In his work, "Big Man," presidentialism, corruption, and clientelism are the three dimensions of neo-patrimonial rule. ${ }^{248}$ These scholars share an important intuition: if the paramount leader loses power, all those who belong to his inner circle or have access to state resources through him will lose their benefits. Loyalty to the leader conflates almost perfectly with the subordinate's self-interest. The well-being of these high-level clients is intertwined with their patron's future in that they do have an interest in fighting fiercely if they perceive their patron's tenure in power to be shaky. Finally, Escribà-Folch and Wright found evidence that, lacking an exit strategy with guarantees for former leaders during and after transition, "personalist dictatorships are less likely to democratize when more of their neighbors prosecute human rights abusers."249

With nine situations concerning eight African states and two more preliminary examinations pending, ${ }^{250}$ the ICC staff would benefit tremendously from improving their comprehension of African politics. Since most ICC officials have studied and practiced law in either Europe or America, they are, albeit unwillingly, responsible for furthering the Court's Euro-centric bias. Unlike the law, politics does not require all actors to be equal and to play by the same rules; it hinges on and reflects local social, cultural, and historical peculiarities. Claiming that world regions are different from one another seems obvious, yet the ICC's

246. Abel Escribà-Folch \& Joseph Wright, Human Rights Prosecutions and Autocratic Survival, 69 INT’L ORG. 343, 351 (2015).

247. Id.

248. Michael Bratton, Formal versus Informal Institutions in Africa, $18 \mathrm{~J}$. DEMOCRACY 96, 98 (2007).

249. Escribà-Folch \& Wright, supra note 246, at 346.

250. See Preliminary Examinations: Completed-Proceeded to Investigation, ICC, https://www.icc-cpi.int/en_menus/icc/structure $\% 20$ of $\% 20$ the $\% 20$ court/office $\% 20$ of $\% 20$ the $\% 20$ prosecutor/comm $\% 20$ and $\% 20$ ref/pe-cpi/Pages/default.aspx (last visited Jan. 31, 2015). 
global mission has apparently excluded geopolitical considerations from the picture. In order to dispel criticism, the OTP should do more than simply look into non-African states; its case selection policy should show greater understanding of African politics. In the end, it takes studying more than law books and statutes. A thorough literature review of the politics of violence is beyond the scope of this article, yet the purpose of this subsection is to add context to a decision-making process that is often - and mistakenly - assumed to be devoid of personal and political tensions.

\section{INTERNATIONAL DETERRENCE AT WORK: THE CASE OF CÔTE D'IVOIRE}

In this section, I identify the empirical conditions that determined whether Gbagbo and his associates would either obey or ignore international laws under the constant threat of ICC prosecution. Among the many instances in which international and regional actors voiced the threat of ICC prosecution, this section examines three episodes displaying significant variation in outcomes. Methodologically, it can be said that Côte d'Ivoire amounts to an ideal case study in that it allows for controlling several potential causal variables, first of all the mere threat of ICC prosecution. Furthermore, the selected episodes show that the typology of state strategies illustrated in Table 2 is dynamic in that it allows for movement from one quadrant to another. As shown in Table 3 below, these episodes cover three of the four possible outcomes discussed in the previous section. From a different viewpoint, dynamism across quadrants proves that: 1) external factors intervening in one or both IVs may alter threat perception in he who is the target of that threat; and 2) Ivorian leadership did, in fact, adjust its strategy in response to changing signals.

This section is organized as follows. First, I first examine episode CIV $(1)^{251}$ in which the threat of ICC prosecution worked as expected and deterred the escalation of mass violence. Second, I show that leadership's strategy changes with the surrounding political and military

251. See infra Table 3. 
circumstances. In CIV(2), ${ }^{252}$ for instance, Gbagbo's defeat in the 2010 elections and international condemnation of his attempt to forge electoral results are to be interpreted as signals negatively affecting the outlook on leadership survival. Finally, in $\operatorname{CIV}(3)^{253}$ I demonstrate how variation in the threatener's identity alter perceptions held by the threat recipient. To be specific, France posed a credible threat to state leaders for all of the above-mentioned reasons (e.g., history of military interventions in Africa, ${ }^{254}$ troops deployed miles away from Gbagbo's command, ${ }^{255}$ and pro-rebel positions openly upheld during the Linas-Marcoussis peace talks), ${ }^{256}$ while the ECOWAS mission did not (e.g., history of nonintervention among AU members, fewer and ill-equipped troops to confront Ivorian armed forces in combat, and AU members' preference for diplomatic solutions to the crisis). ${ }^{257}$

\begin{tabular}{|c|c|c|}
\hline $\begin{array}{c}\text { International (ICC) } \\
\text { Deterrence }\end{array}$ & $\begin{array}{c}\text { Arrest or } \\
\text { Punishment- } \\
\text { High Likelihood }\end{array}$ & $\begin{array}{c}\text { Arrest or } \\
\text { Punishment- } \\
\text { Low Likelihood }\end{array}$ \\
\hline $\begin{array}{c}\text { Leadership } \\
\text { Survival- } \\
\text { Positive Outlook }\end{array}$ & $\mathrm{CIV}^{*}(1)$ & KENYA \\
\hline $\begin{array}{c}\text { Leadership } \\
\text { Survival- } \\
\text { Negative Outlook }\end{array}$ & $\mathrm{CIV}(2)$ & $\mathrm{CIV}(3)$ \\
\hline
\end{tabular}

Table 3 - *Côte d'Ivoire - International Deterrence: Actual State Strategy Cartography

252. See infra Table 3.

253. See infra Table 3.

254. French assertive foreign policy in the African continent was noted in Jackson \& Rosberg, supra note 202, at 21.

255. Dan Collins, French Face Ivory Coast Unrest, CBS News (Nov. 9, 2004), http://www.cbsnews.com/news/french-face-ivory-coast-unrest/.

256. See Bovcon, supra note 154, at 8.

257. On the African Union "official" stance on military intervention on state members' territory, see generally Paul D. Williams, From Non-Intervention to NonIndifference: The Origins and Development of the African Union's Security Culture, 106 AFR. AFF. 253 (2007). 
On November 6, 2004, the Ivorian air force carried out an attack on Bouaké, the de facto capital of Northern Côte d'Ivoire under rebel control, in broad daylight [CIV(1)]. ${ }^{258}$ In consequence, around ten French soldiers died and thirty more were wounded. ${ }^{259}$ As said, those soldiers were stationed there as part of Opération Licorne. The parties inevitably disagreed as to whether the strike against French soldiers was deliberate or not; Ivorian authorities insisted that it was unintentional, whereas the French government reached the opposite conclusion. ${ }^{260}$ Disagreement notwithstanding, the French army quickly retaliated by destroying the entire Ivorian air force. ${ }^{261}$ In particular, the Dassault Mirage F1 strikers employed in this mission took off from the French military base in Gabon - a detail that stresses the importance of considering offensive power. ${ }^{262}$ French retaliation produced three main effects. First, it sent a clear signal about France's willingness and readiness to employ military force. Second, the Ivorian army lost the advantage of air warfare over the insurgency, making it increasingly difficult to hit enemy targets across the buffer zone created and policed by the French peacekeepers. ${ }^{263}$ Third, the Ivorian leadership reacted by inciting violence against French expatriates and businesses through state-controlled mass media (radio and TV in particular). ${ }^{264}$

258. See supra Table 3.

259. Damien McElroy, French Troops Die in Ivory Coast Flare-up, TELEGRAPH (Nov. 7, 2004), http://www.telegraph.co.uk/news/worldnews/africaandindianocean/ cotedivoire/1476077/French-troops-die-in-Ivory-Coast-flare-up.html.

260. Chirot, supra note 141, at 73.

261. Akhavan, supra note 13, at 639; McGovern, supra note 20, at 79; Wyss, supra note 183 , at 93 .

262. WALT, supra note 144, at 24-25.

263. Bearing in mind the precedent of Chad in the early 1980s, the Ivorian leadership had valid reasons to be concerned about this development, along with the military and political consequences that might have followed. In short, the interposition of the Organization of African Unity force between government and opposition troops allowed the latter to regroup and then launch a successful offensive against the incumbent regime of Goukouni Oueddei. ClaPHAM, supra note 159, at 237-38.

264. Akhavan, supra note 13, at 639; see also Chirot, supra note 141, at 73. Incendiary rhetoric notwithstanding, peace negotiations held from December 2002 to January 2003 had already proved President Gbagbo utterly weak vis-à-vis the French 
Two other important events belong in the causal chain that eventually led to the de-escalation of the crisis. First, in Resolution 1572 the Security Council demanded that the Ivorian government stop all broadcasting that incited hatred. ${ }^{265}$ Second, Juan Méndez, UN Special Adviser on the Prevention of Genocide, warned state authorities that, had inaction by domestic courts persisted, incitement to commit violence would have fallen under ICC jurisdiction. ${ }^{266}$ Shortly thereafter, the broadcasting of appeals to violence suddenly stopped. ${ }^{267}$ Hence, the question is, what induced the Ivorian leadership to change behavior? Was it a single factor or a combination thereof? Akhavan identifies the ICC as the cause of such a change. In his words, earlier threats of ICC prosecution were less credible because the Court was barely established. ${ }^{268}$ In November 2004, however, the ICC was up and running and projected a credible threat onto Gbagbo and his associates. ${ }^{269}$ Relatedly, Akhavan maintains that the absence of arrest warrants or pending trials have not dampened the Court's deterrence impact. ${ }^{270}$ For him, a functioning ICC was basically sufficient to bring about successful deterrence. ${ }^{271}$

Conversely, in the present account, Akhavan's "functioning" ICC loses its explanatory power and is regarded as constant. Methodologically, the reason for this downgrade is easy to grasp. Mass atrocities continued to occur long after the ICC began to function, which is tantamount to saying that the threat of prosecution before the ICC is still insufficient in deterring international crimes. Both comparative and diachronic evidence support the foregoing conclusion. From a comparative viewpoint, it is possible to list a number of cases wherein the perceived utility of using unconstrained violence outweighed the risk

government-weakness further confirmed by the fact that he eventually, albeit unwillingly, agreed to sign the agreement on January 23, 2003. See Bovcon, supra note 152, at 8; Piccolino, supra note 168 , at 2,6 .

265. S.C. Res. 1572 - 1 (Nov. 15, 2004).

266. Akhavan, supra note 13, at 639.

267. Id. at 640 .

268. Id.

269. Id

270. Id.

271. Id. 
of incurring ICC prosecution. These cases include, as mentioned, Sudan, Kenya, Libya, and Guinea. From a diachronic viewpoint, by November 2010 Gbagbo had ordered loyalist troops to employ violence against enemies and civilians. ${ }^{272}$ At that time, however, the ICC had already investigated and tried a small group of defendants. ${ }^{273}$ If not the threat of sanctions, some other factors must account for the above-said change of behavior.

Here I contend that a favorable combination of circumstances induced Ivorian leaders to believe that compliance was in their best interest. First, retaliation against the Ivorian air force demonstrated beyond a doubt that France was a credible threat in theory and in practice. The latter's use of military force not only eradicated any possible misperceptions about its commitment, but it also exemplified how coercion can be instrumentally employed to deter large-scale atrocities. ${ }^{274}$ Second, as of November 2004 the Ivorian leadership held a quite positive outlook about retaining power in the short-run. Gbagbo's government actively undermined any attempts to implement the January 2003 Linas-Marcoussis power-sharing agreement and bought more time by formally agreeing to the July 2004 Accra III agreement. ${ }^{275}$ Gbagbo's five-year mandate formally expired in November 2005, with the incumbent enjoying the advantage of controlling the electoral machine. ${ }^{276} \mathrm{He}$ also retained the power to declare a state of emergency - a power that allowed him to postpone the 2005 elections to the fall of 2008 despite international criticism. ${ }^{277}$ Relatedly, at that time the ICC had not yet taken any formal measures

272. On post-electoral violence perpetrated by pro-Gbagbo forces, see Straus, supra note 61, at 483-84; Bellamy \& Williams, supra note 61 , at 832.

273. Indeed, by the fall of 2010, the ICC had already begun the trial of Thomas Lubanga Dyilo, Germain Katanga, and Mathieu Ngudjolo Chui in the DRC case; of JeanPierre Bemba Gombo in the CAR case; of Bahar Idriss Abu Garda and Abdallah Banda Abakaer Nourain in the Sudan-Darfur case. Also, arrest warrants were issued with regard to Uganda, the DRC, CAR, and Sudan-Darfur cases.

274. See Smidt, supra note 3, at 176.

275. See COLLIER, supra note 158, at 164.

276. Id. at 165-66. For another instance of Gbagbo's exploiting the advantages of incumbency, see Abu Bakarr Bah, Democracy and Civil War: Citizenship and Peacemaking in Côte d'Ivoire, 109 Afr. AfF. 597, 614 (2010).

277. See Piccolino, supra note 168, at 5, 10. 
towards investigating alleged crimes in Côte d'Ivoire. In sum, it is fair to conclude that the Ivorian leadership decided to refrain from further incitements of violence out of self-interest. From a game-theory standpoint, the pay-off structure was aptly designed as to make compliance with ICC norms more convenient than defiance.

The second Ivorian civil war broke out in the aftermath of the 2010 presidential elections. After having won the first electoral round, Gbagbo lost the runoff to Ouattara by a fair margin ( $46 \%$ to $54 \%$, with a difference of approximately 375,000 ballots). ${ }^{278}$ However, Gbagbo's refusal to hand over the presidency to Ouattara led to a paradoxical situation. On one hand, he still physically controlled the state apparatus, including the army. On the other hand, the international community quickly recognized Ouattara as the legitimate president. ${ }^{279}$ Government de-recognition achieved more than loss of membership in intergovernmental organizations, as it enhanced Ouattara's external and internal legitimacy at Gbagbo's expense. This sudden, and to some extent, unexpected, loss of legitimacy dramatically worsened the leadership's outlook on their political survival. As a result, in $\operatorname{CIV}(2)^{280}$ we observe variation on the leadership survival variable, while the likelihood of arrest or punishment remains constant. Lack of variation in the latter depends on France maintaining its role of enforcer on the ground.

CIV(2) is salient in that it exposes the limits of classic LDT. In particular, CIV(2) accounts for why Gbagbo changed his strategy and ordered the use of violence against civilians. Given the constant threat of ICC prosecution, his decision appears to contradict the rationality postulate. Even IR-based deterrence theory fails to account for this change. Only by bringing in expectations on leadership survival is it possible to shed light on the dramatic choice Gbagbo confronted in the aftermath of the 2010 electoral results. The fact that he eventually opted for what I label 'all-in' strategy demonstrates his will to hold on to power at all costs. From his choice, we can infer that the risk of facing justice became Gbagbo's second-worst outcome. Violence and risk-prone

278. Gagnon, supra note 216, at 54.

279. Wyss, supra note 183, at 95.

280. See supra Table 3. 
behaviors reinforced one another and jointly contributed to the escalation of violence. On one hand, worsening conditions call for risk-prone strategies - strategies that entail even greater violence in the future. ${ }^{281} \mathrm{On}$ the other hand, the violence perpetrated represents a sunk cost which further discounts the adoption of riskier strategies.

In spite of this spiraling violence, France did nothing to find a political solution to the crisis. It never offered Gbagbo amnesty, let alone a way to retain, in whole or in part, political power. By the opposite token, the French government aimed at a military conclusion to the conflict. On March 21, 2011, Sarközy's adviser, Henri Guaino, announced that the French government was optimistic about pushing Gbagbo out of office. ${ }^{282}$ On April 3, 2011, Paris increased the Operation Licorne military contingent from 300 to 1,400 units. ${ }^{283}$ On April 10, 2011 (i.e., the day before Gbagbo's arrest), French forces, in coordination with UN Operation in Côte d'Ivoire (UNOCI) blue helmets, launched an operation targeting heavy weaponry batteries in response to attacks carried out by pro-Gbagbo militias. ${ }^{284}$ Unlike other regional and international actors, France stood firm and refused to negotiate with Gbagbo's illegitimate government. In conclusion, France proved its reputation for resolve by upholding a coherent foreign policy and military strategy along the entire course of the first and second Ivorian civil wars.

281. This risk-dominant attitude observed in despots whose political survival is at stake recalls Bueno de Mesquita and Siverson's argument about variation in war participation between democratic and non-democratic leaders. Bruce Bueno de Mesquita \& Randolph M. Siverson, War and the Survival of Political Leaders: A Comparative Study of Regime Types and Political Accountability, 89 AM. PoL. ScI. ReV. 841, 852 (1995).

282. France to Negotiate Gbagbo's Ouster, Says Sarkozy Adviser, Radio FranCE INTERNATIONALE (Mar. 21, 2011), http://www.english.rfi.fr/africa/20110321-francenegotiate-gbagbo-s-ouster-says-sarkozy-adviser.

283. French Take Control of Abidjan Airport, RAdio FranCE InTERnATIONALE (Apr. 3, 2011), http://www.english.rfi.fr/africa/20110403-french-take-control-abidjanairport.

284. UN Forces Begin Operation in Ivorian City in Response to Attack by ProGbagbo Forces, ReliefWeB (Apr. 10, 2011), http://reliefweb.int/report/côte-divoire/unforces-begin-operation-ivorian-city-response-attack-pro-gbagbo-forces. 
Yet, France was not the only international actor attempting to bring the Ivorian crisis to an end. In the months following the 2010 presidential elections and the outbreak of the second Ivorian civil war (conventionally, November 28, 2010-April 11, 2011) a panoply of foreign actors and IGOs seized the initiative. As I illustrate below, however, the signals they conveyed were predominantly incoherent and, accordingly, Gbagbo's illegitimate government did not perceive them as capable of further threatening its already shaky survival prospects $[\mathrm{CIV}(3)] \cdot{ }^{285}$ Both CIV(2) and CIV(3) belong to the lower row of Table 2, but in the latter the threatened perceived a low(er) risk of arrest or punishment. Examining CIV(3) shows how variation in the enforcer affects the success (or failure) of deterrence. ECOWAS leaders were among the first to get involved in the Ivorian crisis and work for a diplomatic solution thereto. Frustrated by Gbagbo's refusal to step down and flee the country, the ECOWAS suspended Côte d'Ivoire membership on December 7, 2010. ${ }^{286}$ On December 18, 2010, Nigerian President Goodluck Jonathan, as chairman of the ECOWAS, co-signed AU Commission chief Jean Ping's letter to Gbagbo, endorsing the latter's call for Gbagbo's resignation. ${ }^{287}$ Yet, only four days later the same IGO offered Gbagbo asylum in Nigeria - an offer repeated by Kenyan Prime Minister Raila Odinga on December 28 and again by President Thomas Boni Yayi of Benin, President Ernest Bai Koroma of Sierra Leone, President Pedro Pires of Cape Verde, and Prime Minister Raila Odinga of Kenya on January 5, 2011. ${ }^{288}$ There is more; while offering Gbagbo asylum, the above countries (individually or collectively under the

285. This statement is consistent with Jack Snyder and Robert Jervis' finding that "[c]redibility problems are exacerbated . . . when the intervener is not a unitary actor." Jack Snyder \& Robert Jervis, Civil War and the Security Dilemma, in CIVIL WARS, INSECURITY, AND INTERVENTION 33 (Barbara F. Walter \& Jack L. Snyder eds., Columbia Univ. Press 1999). See also supra Table 3.

286. Pressure Mounts for Power Handover in Côte d'Ivoire, RADIO FRANCE INTERNATIONALE (Dec. 7, 2010), http://www.english.rfi.fr/africa/20101207-pressuremounts-power-handover-cote-divoire.

287. Rebecca Friedrichs, Timeline: Election Crisis in Côte d'Ivoire, Stimson, http://www.stimson.org/images/uploads/research-pdfs/Timeline_Election_Crisis_in_ Cte_dIvoire.pdf (last visited Feb. 2, 2015).

288. Id. 
ECOWAS banner) threatened to oust him from power on December 24 and $28 .{ }^{289}$ In particular, on December 28, 2010, Gbagbo received both an offer of asylum from Kenyan Prime Minister Raila Odinga and a threat of military intervention from Benin's Boni Yayi, Sierra Leone's Ernest Bai Koroma, and Cape Verde's Pedro Pires. ${ }^{290}$ The lack of coordination among different actors is appalling. Further, ECOWAS members' diplomatic incoherence signaled limited resolve in ordering peacekeepers to engage more actively in war operations. ${ }^{291}$ In the end, it suffices to say that, when deciding how to react to these threats, Gbagbo "stood firm and called their bluff." 292 But AU and ECOWAS member states were not alone in alternating stick and carrot with fallen president Gbagbo, the United States being another notable example. On this point, the Obama administration preferred to engage Gbagbo diplomatically. Alongside private talks, on December 9, 2010, President Barack Obama publicly warned Gbagbo of "consequences" if the latter did not step down and transfer power to his successor peacefully. ${ }^{293}$ State Department spokesman P.J. Crowley echoed Obama's warning, adding that the US government had begun studying what sanctions to apply to Gbagbo and his closest associates in case they did not give in to international pressures. $^{294}$ On January 3, 2011, however, a delegation of African leaders leaked that the US had offered him a "dignified exit." ${ }^{295}$ After backchannel diplomacy failed, US strategy changed again on January 25, 2011, when the Obama administration publicly agreed to support Ouattara's call for temporary trade embargo (i.e., a month-long ban on

289. Id.

290. Id.

291. For another example of multiple political actors conveying incoherent foreign policy signals, see KenNeth A. Schultz, Democracy AND Coercive Diplomacy 193 (Cambridge Univ. Press 2001).

292. Bellamy \& Williams, supra note 61 , at 834.

293. Rukmini Callimachi, US Threatens Sanctions Against Ivory Coast, Bos. GLOBE (Dec. 9, 2010), http:/www.boston.com/news/world/africa/articles/2010/12/09/us threatens_sanctions_against_ivory_coast/.

294. Id.

295. US Offers Ivory Coast's Laurent Gbagbo 'Dignified Exit', BBC NEws (Jan. 4, 2011), http://www.bbc.com/news/world-africa-12106533. 
cocoa exports). ${ }^{296}$ In all, the US government proved hesitant to get involved in Côte d'Ivoire. There are at least two considerations that explain why the US adopted a soft response to the Ivorian crisis. First, from a geopolitical standpoint, the US had no reason to "feel responsible" for Côte d'Ivoire, since the latter fell in the French sphere of influence. ${ }^{297}$ Second, from a normative standpoint, it is plausible to assert that the US was unwilling to resort to military force because of its official stance on the ICC.

In sum, it might be appropriate to categorize foreign actors and IGOs depending on whether or not they threatened the use of force against Gbagbo's illegitimate government. Among those who did not threatened Gbagbo militarily, many advocated for and eventually undertook political and/or economic sanctions. The Security Council extended the UNOCI mandate, despite Gbagbo's objections; the European Union imposed targeted sanctions, including a ban on visas and financial assets, against Gbagbo, his wife and nineteen other Ivorians - sanctions that later extended to a total of fifty-nine Gbagbo supporters; the World Bank suspended funding to Côte d'Ivoire, while the Central Bank of West African States blocked Gbagbo's access to state funds. ${ }^{298}$ Lastly, Switzerland froze Gbagbo's personal assets. ${ }^{299}$ In theory, deterrence can be achieved also by non-military means. Economic and political sanctions can alter the risk calculus and, in turn, induce change in behavior. That said, unarmed threats were simply ill-timed to constrain decision-making by the Ivorian leadership, as the latter already held a negative outlook on regime survival. In order to maximize the deterrent impact of these measures, I claim that they should rather be adopted in the upper-right quadrant of Table 2, when the risk of arrest or

296. Ivory Coast Cocoa: US Backs Ban, Cargill Stops Trade, BBC NEws (Jan. 25, 2011), http://www.bbc.com/news/world-africa-12274696.

297. According to Shaun Gregory, "[o]ne reason for the French dominance of Francophone Africa (though one which is deeply unpalatable in France), was American indulgence, underpinned by a broad alignment of shared interests [during the Cold War]." Gregory, supra note 157, at 436.

298. Laurent Gbagbo Denied Access to Ivory Coast State Funds, BBC News (Dec. 24, 2010), http://www.bbc.com/news/world-africa-12072550.

299. Friedrichs, supra note 287. 
punishment is low but the leadership remains nevertheless confident about holding on to power in the short-run.

France aside, few other states actually threatened to resort to military force against Gbagbo's government. The US, despite its ability to project power globally, lacked intrinsic and strategic interest to credibly commit as enforcer. Besides, it would have been odd for the US to uphold the threat of ICC prosecution after having openly opposed the Court and convinced over one hundred states to sign bilateral non-surrender agreements. ${ }^{300}$ Regarding the United Kingdom, it was Foreign Secretary William Hague who voiced the threat of military intervention in hopes of deterring further humanitarian violations. ${ }^{301}$ On this point, the UK's authentic support of the ICC could amount to intrinsic interest, yet there was no specific reason for the British government to intervene in Côte d'Ivoire among several war threats active at that time. Apart from the lack of strategic interest, the UK did not enjoy the same reputation for resolve in Africa that France did, as its limited military mission in Sierra Leone demonstrated. ${ }^{302}$ Lastly, the ECOWAS had, on the ground, a significant military contingent serving alongside the Opération Licorne contingent. The military mission deployed in Côte d'Ivoire since fall 2002 was later replaced by the UNOCI, but many ECOWAS member states extended their commitment under UN auspices. ${ }^{303}$ While it is debatable whether or not that military presence posed a serious threat to Gbagbo's regime, I argue that the many state identities inhabiting the ECOWAS undermined the signaling of a coherent collective commitment. In the end, African states once again upheld their

300. For a political analysis of bilateral non-surrender agreements, see Judith Kelley, Who Keeps International Commitments and Why? The International Criminal Court and Bilateral Nonsurrender Agreements, 101 AM. PoL. SCI. REV. 573 (2007). For a legal analysis, see David J. Scheffer, Article 98 (2) of the Rome Statute: America's Original Intent, 3 J. INT'L CRIM. JUST. 333 (2005).

301. Friedrichs, supra note 287.

302. Scott Bade, The British Aren't Coming: Why the French Intervene in Their Former Colonies and the British Do Not 58-59 (May 22, 2013) (unpublished honors thesis, Stanford University) (on file with Stanford Center for International Security and Cooperation), available at http://iis-db.stanford.edu/docs/785/Bade_Scott_Thesis_ Final.pdf.

303. Piccolino, supra note 168, at 9-11; Wyss, supra note 183, at 92. 
preference for non-intervention in domestic affairs. Even after nonAfrican countries decided to employ military force, they pursued a suboptimal strategy that consisted of minimal interference, and were proactive in setting forth diplomatic solutions to the crisis.

In conclusion, the case of Côte d'Ivoire is tremendously helpful in illustrating my argument because it allows for within-case variation. The first factor that makes this case study unique is the presence of a serious enforcer. France had intrinsic and strategic interest, strong commitment, and the military capability to successfully deter the Ivorian leadership from escalating violence. Thanks to France, Gbagbo and his associates correctly decoded and believed the threat of being ousted from power coercively and brought before the ICC. And the role of France must be further emphasized, as its reputation for resolve might have actually crossed state borders and convinced the Guinean military junta to cooperate with the Court on the investigation and prosecution of the September 28, 2009 events. $^{304}$ But the case of Côte d'Ivoire also demonstrates that it is no longer possible to ignore the circumstances under which state leaders decide to unleash violence. In the aftermath of the 2010 presidential elections, Gbagbo and his associates saw no option but to resist. Moreover, the same circumstances justified, at least in their minds, the adoption of risk-prone strategies that called for even greater violence. The investigation of leaders' evolving interests and perceptions over the entire Ivorian crisis has also confirmed a long-known truth about deterrence: For the latter to succeed, he who is under threat must have, or perceive to have, something worthwhile to lose. In this regard, the enforcer's task is two-fold. First, it is crucial to identify what interests are dear to the threatened and to know how the threatened ranks them. On this point, the case of Côte d'Ivoire shows that assumptions can be misleading rather than useful. Despite many offers of asylum, for instance, Gbagbo decided not to flee the country and fight for power. In this case, empirical evidence suggests that he valued his political survival at least as much as, if not more than, his physical one. Second, the enforcer must adjust his strategy to the surrounding circumstances. There

304. Guinea, ICC, http://www.icc-cpi.int/en_menus/icc/structure $\% 20$ of $\% 20$ the $\% 20$ court $/$ office $\% 20$ of $\% 20$ the $\% 20$ prosecutor/comm $\% 20$ and $\% 20$ ref/pe-ongoing/guinea/ Pages/guinea.aspx (last visited May 11, 2015). 
is no abstract policy on which sanctions (or incentives) will be effective. The economic and political sanctions imposed by the above-mentioned IGOs failed to deter new atrocities because they did not target the physical or political survival of Ivorian leaders. Simply put, they missed the target. By the same token, offering amnesty or asylum to violent entrepreneurs who do not fear immediate retribution for their crimes might be interpreted as a sign of the enforcer's weakness or lack of commitment. ${ }^{305}$

\section{CONCLUSIONS AND POLICY RECOMMENDATIONS}

This research project examines the circumstances under which the threat of ICC prosecution proved successful in deterring the commission or escalation of mass atrocities. Findings from the case of Côte d'Ivoire confirm that the threat of facing justice in The Hague might, under specified circumstances, contribute to the de-escalation of violence. However, such a threat is worth little if not backed up by a major power willing to bear the political and economic costs of enforcing ICC decisions. To deter new atrocities, it is also crucial for the enforcer to have leverage on the threatened. If the latter has nothing to lose, ICC threats will either have no effect on violence or exacerbate the level thereof. The proposed state strategy typology illustrated in Table 2 aptly captures these causal variables. The likelihood of arrest or punishment is a function of threat credibility, which in turn hinges on the enforcer's credibility. Drawing on classic IR theory, I analyze how an enforcer conveys a strong threat to the chosen recipient. The stronger the threat, I claim, the smaller the risk of the threatened misperceiving the signal. That said, a credible threat depends on state interest and commitment. Albeit analytically distinct concepts, military capability and reputation for resolve add credibility to state commitment during the bargaining phase. Empirically, only France, among the many actors who confronted Gbagbo's government, was able to convey a strong signal, inducing domestic decision-makers to refrain from escalating violence in

305. Payam Akhavan makes a similar comment regarding Revolutionary United Front leader Foday Snakoh and his interpretation of the amnesty granted to him and his combatants in the 1999 Lomé Peace Accord. See Akhavan, supra note 13, 635-36. 
November 2004. The empirical analysis of Côte d'Ivoire also shows that a credible threat is necessary but insufficient to bringing about compliance with ICC norms through deterrence; due attention must be paid to the threatened himself, especially to whether or not he holds a positive short-term outlook about retaining power. When that outlook is negative, instead, the intervening threat of ICC prosecution could cause what in the legal literature is referred to as "Peace vs. Justice." ${ }^{" 306}$ Beyond the empirical analysis of a single case study, this project carries several implications for the study of deterrence at the international level. The first and foremost implication is that, when moving from the domestic to the international level, it is no longer possible to overlook political considerations. Methodologically, the threat of ICC prosecution is to be regarded as a necessary but trivial condition if we examine cases of mass atrocities occurring before and after its entry into force on July 1, 2002. When we carry out a comparative analysis of cases that occurred after that date, the threat of ICC prosecution loses its residual explanatory power and becomes a constant. In all, the fact that episodes of mass violence have continued to occur, even after the ICC was established and entered into force, demonstrates that we should search elsewhere for causal inference. This is where legal and IR scholars diverge in seeking explanations as to what determines whether deterrence will succeed or fail in coercing compliance. Legal scholars insist on intervening in the institutional design of laws and tribunals, while their IR colleagues go beyond the incentive structure and examine the relationship between players. This article offers a two-fold argument to review the mainstream rationalist approach so dear to legal scholars. The first one, as already mentioned, is empirical. The mere existence of a permanent criminal court in the Hague did not prevent several new episodes of violence from breaking out. The second argument is analytical. LDT pinpoints three main factors in the threat of criminal sanctions deterring future crimes. Among these three, certainty of punishment holds a greater causal power than the other two (severity and celerity of punishment). But the drafters of the Rome Statute intentionally outsourced the certainty factors to

306. Alexander, supra note 6, at 30. 
states. As a result, deterrence is now mostly exogenous to the body of law we refer to as international criminal law.

But acknowledging the limits of the ICC legal and institutional scaffolding is not tantamount to downplaying, let alone to ignoring, the salient novelties introduced by the Rome Statue. In this article I duly emphasized the scholarly claim that the ICC represents a step forward in deterring episodes of mass violence. ICC temporal and (potentially unlimited) territorial jurisdiction amounts to a necessary premise for potential criminals to perceive the threat of criminal sanctions upon them. Furthermore, its unprecedented legal flexibility allows the OTP to intervene in ongoing conflicts in order to deescalate mass violence. Yet, I contend that the ICC is nowhere close to fully exploiting its preventive potential. Perhaps the most important limit to improving the ICC's deterrent impact is endogenous to the Court and, in particular, to those who work therein. By conceiving of the ICC exclusively as a judicial body, they knowingly neglect the international dimension thereof. Paraphrasing Akhavan's words, it is time to allow political realism to complement - if not to dismiss - the dominant romantic view on what the ICC is, as well as what is meant to accomplish. ${ }^{307}$ It is also crucial for professionals and scholars alike to further explore the analytical distinction between the commission and escalation of mass violence, and the role the ICC can play in each. On this point, this study illustrates that the threat of ICC prosecution can, under specified circumstances, deter the escalation of violence.

The above-said distinction is also salient in that it provides the opportunity to learn from IR deterrence theories. Escalation intuitively differs from commission in that the former entails some violent, and likely criminal, acts have occurred before the threat of ICC prosecution intervenes. In a legal debate still dominated by a rationalist understanding of deterrence, it follows that the timing of threat issuance determines whether or not incurring criminal sanctions can alter the risk calculus of self-interested actors. This reasoning also highlights the

307. Akhavan, supra note 13, at 636. On the opportunity to bring in political considerations, see also Rudolph, supra note 17; see generally JACK L. GOLDSMITH \& Eric A. Posner, The Limits of International Law (Oxford Univ. Press 2005); Snyder \& Vinjamuri, supra note 83. 
theoretical salience of the gravity threshold envisaged by the Rome Statute - a potential game changer in shaping OTP incremental strategies devised in response to ongoing conflicts. Building on immediate deterrence, the OTP can match threat seriousness with the increasing level of violence perpetrated until the gravity threshold is finally met; general warnings may turn into a preliminary examination, followed by the opening of a formal investigation and the issuance of indictments and arrest warrants. The suggested logic works on perpetrators' perceptions through strengthening the signal the OTP conveys to them as violence unfolds.

Two recommendations follow. From a policy perspective, the OTP should devise a coherent plan on how to prevent the escalation of mass violence. In particular, targeted individuals must be able to readily and correctly decode OTP measures. For such a strategy to work, however, the OTP should also provide guidance as to when the gravity threshold is met. In a Court allowing limited space for realpolitik considerations, it is unlikely to obtain quantitative and qualitative guidelines on how to ex ante pinpoint precisely where the threshold is to be set. From a legal perspective, scholars and practitioners should refrain from importing domestic assumptions into the study of international deterrence. Indeed, the difference between domestic and international deterrence goes beyond the level of analysis, as each uses a distinct set of working assumptions. Most importantly, international deterrence requires researchers to identify who is the source of the threat, whereas domestic deterrence holds constant the role of the state as the coercive agent. Extended deterrence affords a new theoretical framework to search for the source of the threat. Put simply, potential perpetrators do not fear the ICC, which lacks enforcement powers, but rather the state (or collection thereof) that seriously commits to enforcing ICC decisions.

In conclusion, this Article challenges the ubiquitous assumption that the ICC can deter future atrocities and finds evidence that, under specified circumstances, the threat of ICC prosecution has, in fact, prevented the escalation of atrocities in Côte d'Ivoire. Despite its limited scope, this Article has significant implications for future research. First, it provides the necessary empirical foundation for studying how states and IGOs can actually use the threat of international prosecution as a political resource for conflict resolution or a bargaining chip in 
diplomatic negotiations. Second, it shows that major powers retain a special role in determining successful deterrence. ${ }^{308}$ The case of Côte d'Ivoire further illustrates that realist considerations of power are necessary, yet not sufficient in coercing compliance with international laws. Because of the unique relationship between France and Côte d'Ivoire, however, it is difficult to analytically disaggregate the threat and pinpoint which factor(s) held the greatest causal effect. Since findings drawn from a single case do not allow for generalization, it is only possible to speculate that an asymmetric — or hierarchical in Lake's terms - relationship between enforcer and threatened is both necessary and sufficient to convey a credible threat to the latter. This speculation can be reformulated into a hypothesis and tested in future studies. Lastly, this Article stresses the importance of state leaders' perceptions. Considerations on leadership survival in the short-run may be the key to predicting whether the threat of ICC prosecution will either deter or exacerbate the escalation of mass atrocities.

308. Mohammed Ayoob makes a similar argument on the special role major powers ought to play in cases of humanitarian intervention. In his words, indeed, "[t]he responsibility for maintaining international order, and the credibility and legitimacy of such an order, lies squarely on the shoulders of the major powers . . ." Mohammed Ayoob, Third World Perspectives on Humanitarian Intervention and International Administration, 10 Global Governance 99, 113 (2004). Similarly, Hedley Bull describes great powers as the "great responsibles" in preserving order in the international system. Hedley Bull, The Anarchical Society: A Study of Order in World Politics 49 (4th ed. 2012). 